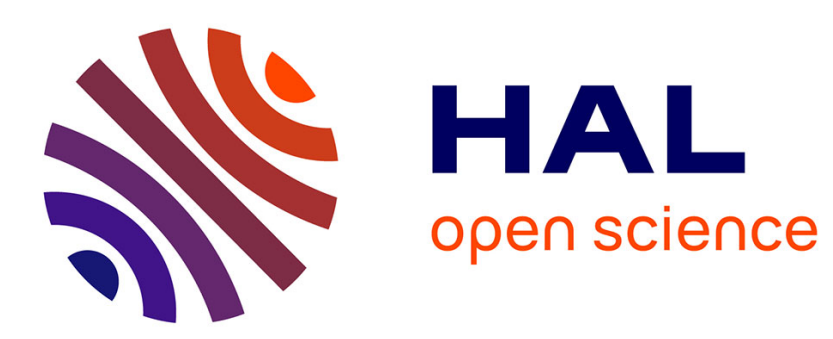

\title{
South Pacific mantle plumes imaged by seismic observation on islands and seafloor
}

D. Suetsugu, T. Isse, S. Tanaka, M. Obayashi, H. Shiobara, H. Sugioka, T. Kanazawa, Y. Fukao, Guilhem Barruol, D. Reymond

\section{- To cite this version:}

D. Suetsugu, T. Isse, S. Tanaka, M. Obayashi, H. Shiobara, et al.. South Pacific mantle plumes imaged by seismic observation on islands and seafloor. Geochemistry, Geophysics, Geosystems, 2009, 10 (11), pp.Q11014. 10.1029/2009GC002533 . hal-00443845

\section{HAL Id: hal-00443845 \\ https://hal.science/hal-00443845}

Submitted on 26 Oct 2016

HAL is a multi-disciplinary open access archive for the deposit and dissemination of scientific research documents, whether they are published or not. The documents may come from teaching and research institutions in France or abroad, or from public or private research centers.
L'archive ouverte pluridisciplinaire HAL, est destinée au dépôt et à la diffusion de documents scientifiques de niveau recherche, publiés ou non, émanant des établissements d'enseignement et de recherche français ou étrangers, des laboratoires publics ou privés. 


\title{
South Pacific mantle plumes imaged by seismic observation on islands and seafloor
}

\section{Suetsugu}

Institute of Frontier Research on Earth Evolution, Japan Agency of Marine-Earth Science and Technology, 2-15 Natsushima-cho, Yokosuka, Kanagawa 237-0061, Japan (dai@jamstec.go.jp)

T. Isse

Earthquake Research Institute, University of Tokyo, 1-1-1 Yayoi, Bunkyo-ku, Tokyo 113-0032, Japan

\section{S. Tanaka and M. Obayashi}

Institute of Frontier Research on Earth Evolution, Japan Agency of Marine-Earth Science and Technology, 2-15 Natsushima-cho, Yokosuka, Kanagawa 237-0061, Japan

\section{H. Shiobara}

Earthquake Research Institute, University of Tokyo, 1-1-1 Yayoi, Bunkyo-ku, Tokyo 113-0032, Japan

\section{H. Sugioka}

Institute of Frontier Research on Earth Evolution, Japan Agency of Marine-Earth Science and Technology, 2-15 Natsushima-cho, Yokosuka, Kanagawa 237-0061, Japan

\section{T. Kanazawa}

Earthquake Research Institute, University of Tokyo, 1-1-1 Yayoi, Bunkyo-ku, Tokyo 113-0032, Japan

\section{Y. Fukao}

Institute of Frontier Research on Earth Evolution, Japan Agency of Marine-Earth Science and Technology, 2-15 Natsushima-cho, Yokosuka, Kanagawa 237-0061, Japan

\section{G. Barruol}

Géosciences Montpellier, Université Montpellier II, CNRS, Place E. Bataillon, F-34095 Montpellier CEDEX 5, France

\section{Reymond}

\author{
Laboratoire de Géophysique, Commissariat à l'Énergie Atomique de France, BP 640, Papeete, F-98713 French \\ Polynesia
}

[1] The South Pacific region is characterized by a broadly elevated seafloor known as the South Pacific superswell. This region has a concentration of midplate volcanoes that experienced massive eruptions in the mid-Cretaceous period (90-120 Ma). These characteristics suggest the presence of a large-scale mantle plume beneath the South Pacific, called the South Pacific superplume. The geometry, origin depth, temperature, and composition of the superplume remain controversial, however, mainly due to the lack of seismological data that documents the mantle structure beneath the South Pacific. Seismic stations are sparse in the area due to its remote ocean environment. To obtain a better seismic image of the superplume, we deployed temporary broadband seismographs on oceanic islands and the seafloor in the South Pacific, which made possible the highest spatial resolution that has ever been achieved for the mantle structure 
beneath the region. The seismic image obtained from this new seismic data indicates that large-scale lowvelocity anomalies (on the order of $1000 \mathrm{~km}$ in diameter), indicative of the superplume, are located from the bottom of the mantle to a depth of $1000 \mathrm{~km}$, and small-scale low-velocity anomalies (on the order of $100 \mathrm{~km}$ in diameter) are present above it. A comparison of the seismic image with recent mantle convection studies based upon laboratory and numerical experiments suggests that the superplume may be a hot and chemically distinct mantle dome, and that the small-scale anomalies may be narrow plumes generated from the top of the dome. This model may explain various characteristics of hot spots in the South Pacific, such as the seafloor swell, short-lived hot spot chains, and the periodicity of massive eruptions.

\section{Introduction}

[2] The South Pacific seafloor is characterized by a superswell elevated up to $700 \mathrm{~m}$, in a $3000 \mathrm{~km}$ by $3000 \mathrm{~km}$ area [McNutt and Judge, 1990; McNutt, 1998; Adam and Bonneville, 2005], and a concentration of midplate volcanoes called hot spots. These hot spots include Society, Macdonald, Marquesas, Pitcairn and Arago, which form island chains with a short age progression (4-6 Myr according to Duncan and MacDougall [1976]; shorter than $20 \mathrm{Myr}$ according to Bonneville et al. [2002, 2006]). They produce oceanic island basalt (OIB) with an enriched mantle signature [e.g., Hart, 1984], which suggests that their origin is deep in the mantle. In the Cretaceous period [e.g., McNutt, 1998; Utsunomiya et al., 2007], this region experienced massive eruptions that produced large oceanic plateaus. These phenomena all suggest the presence of a major hot mantle plume, which leads to the hypothesis of a superplume in the deep mantle beneath the South Pacific [Larson, 1991], though its size, origin depth, and even presence remain controversial.

[3] Seismic tomography is the most appropriate technique to examine the deep mantle and to provide the information upon which answers to these questions can be based. This technique images a heterogeneous structure of the Earth's interior using vast amounts of seismic data, using the same principle as that of a medical CT scan.
The higher temperatures of the presumed mantle plumes should appear as regions of slower seismic wave velocities. However, the seismic structure of the mantle beneath the South Pacific superswell has thus far been poorly resolved because of the area's sparsely located seismic stations, which in different studies have produced blurred and even inconsistent images. Some studies have described a whole mantle-scale broad plume [Zhao, 2004], others have proposed a continuous plume conduit generated from a broad plume near the core-mantle boundary [Ritsema and van Heijst, 2000; Montelli et al., 2006; Takeuchi, 2007, 2009], and still others have suggested plumes that do not continue throughout the mantle [Mégnin and Romanowicz, 2000]. In order to obtain an accurate view of the mantle plumes beneath the South Pacific, the first requirement is more thorough coverage of the area by seismic stations. To this end, we therefore performed joint Japanese-French broadband seismological observations on oceanic islands and the seafloor from 2001 to 2005. Until now, the seismic data that was recorded have been widely used to image the mantle structure and its deformation. Upper mantle heterogeneities, anisotropies, and discontinuities have been characterized by surface wave tomography and receiver functions studies [Isse et al., 2006; Maggi et al., 2006a, 2006b; Suetsugu et al., 2007], whereas Tanaka et al. [2009a, 2009b] obtained large-scale slow anomalies of $\mathrm{P}$ and $\mathrm{S}$ waves in the lower mantle using data from the temporary seafloor and islands sta- 


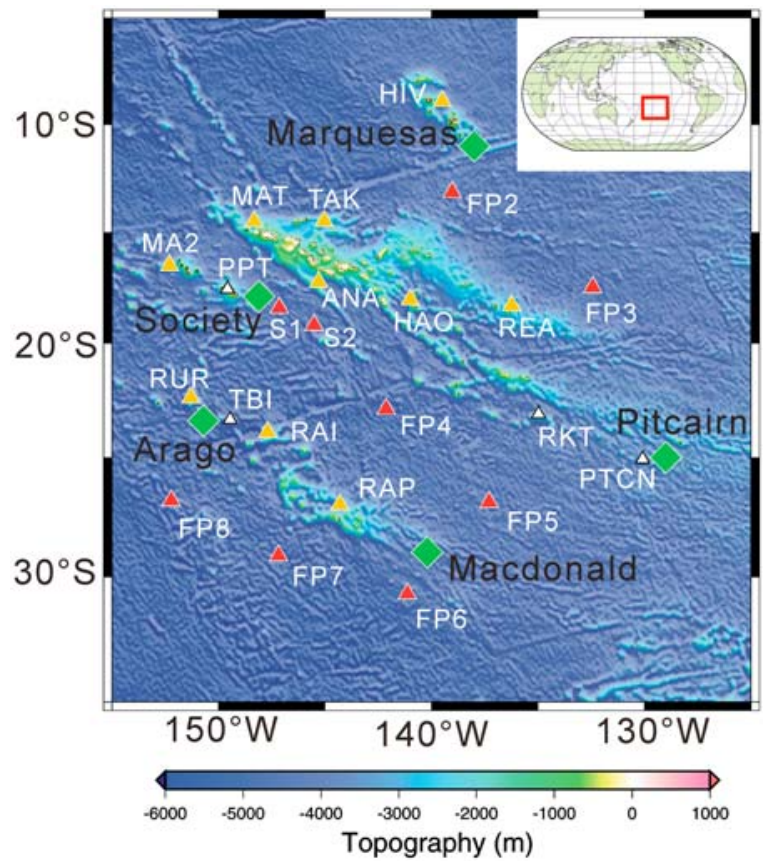

Figure 1. BBOBS (red triangles) and PLUME (yellow triangles) stations shown on a bathymetric map in the French Polynesia region. White triangles are permanent LDG/CEA, IRIS, and GEOSCOPE stations. Green diamonds are active hot spots.

tions. Fontaine et al. [2007, 2009] and Barruol et al. [2009] determined the upper mantle anisotropy using the SKS splitting from the islands stations and seafloor stations, respectively, which can be explained by mantle flow due to motion of the Pacific plate at most stations, and a locally disturbed flow by mantle upwelling near the Society hot spot. However, the structure of the upper mantle and of the mantle transition zone beneath the South Pacific have been studied using the two data sets independently.

[4] The aim of this paper is to present a comprehensive image of the South Pacific mantle plumes across the entire mantle, by conducting a joint analysis of the temporarily available island and seafloor data. Combined with data from the permanent seismic stations, the data from temporary deployments in French Polynesia provided the densest and most uniform station coverage that has ever been achieved in the region. In this study, we obtained the structure of the upper mantle, the mantle transition zone, and the lower mantle separately, by means of surface wave tomography, the receiver function method, and body wave travel time tomography, respectively, which are each suitable for the specific depth range. For the lower mantle structure, we analyzed a preexisting global data set along with the temporary station data that improved the spatial resolution. We then synthesized the structure of the three depth ranges into a whole mantle image of the plumes, which we compared with the recent results of laboratory and numerical experiments in mantle convection to discuss the origin of the mantle plumes and their activity both present and past.

\section{Data}

[5] Before our observations began in 2001, the South Pacific region had been monitored by only six permanent broadband stations, despite the area's widely recognized geophysical and geodynamic significance. We added twenty temporary seismic stations on oceanic islands and the seafloor in the French Polynesian region (Figure 1). From 2001 to 2005, the French team deployed ten broadband seismic stations on the oceanic islands of French Polynesia as part of the Polynesia Lithosphere and Upper Mantle Experiment (PLUME) [Barruol et al., 2002]. From 2003 to 2005, the Japanese team deployed ten broadband ocean bottom seismographs (BBOBS) over the region [Suetsugu et al., 2005a], all on the seafloor at depths of 4000-5000 $\mathrm{m}$. The locations of the BBOBS stations were selected so that they would supplement the oceanic island stations to provide an overall station distribution that was as uniform as possible. The observation period of the BBOBS overlapped that of PLUME for nearly two years. The PLUME seismic system was equipped with an STS-2 broadband seismometer and a 24 bit data acquisition system that continuously recorded data at a sampling rate of $40 \mathrm{~Hz}$. The BBOBS have been developed by the Earthquake Research Institute at the University of Tokyo [Kanazawa et al., 2001] since the 1990s, and are equipped with Guralp CMG-3T seismometers and 24 bit data acquisition systems. Each can continuously record data at a $128 \mathrm{~Hz}$ sampling rate for 400 days. The BBOBS stations were deployed and recovered from the research vessel YOKOSUKA of the Japan Agency for Marine-Earth Science and Technology (JAMSTEC), and the Tahitian fishing boat Fetu Tea II. The ambient noise level estimated on both the islands and the seafloor shows that the vertical component of the noise has amplitudes close to the average noise level observed at land stations all over the world, for periods longer than $10 \mathrm{~s}$ [Barruol et al., 2006]. This indicates that our observations were most suitable for determining the upper mantle structure using Rayleigh waves, and the lower mantle using teleseismic $\mathrm{P}$ waves, since both 


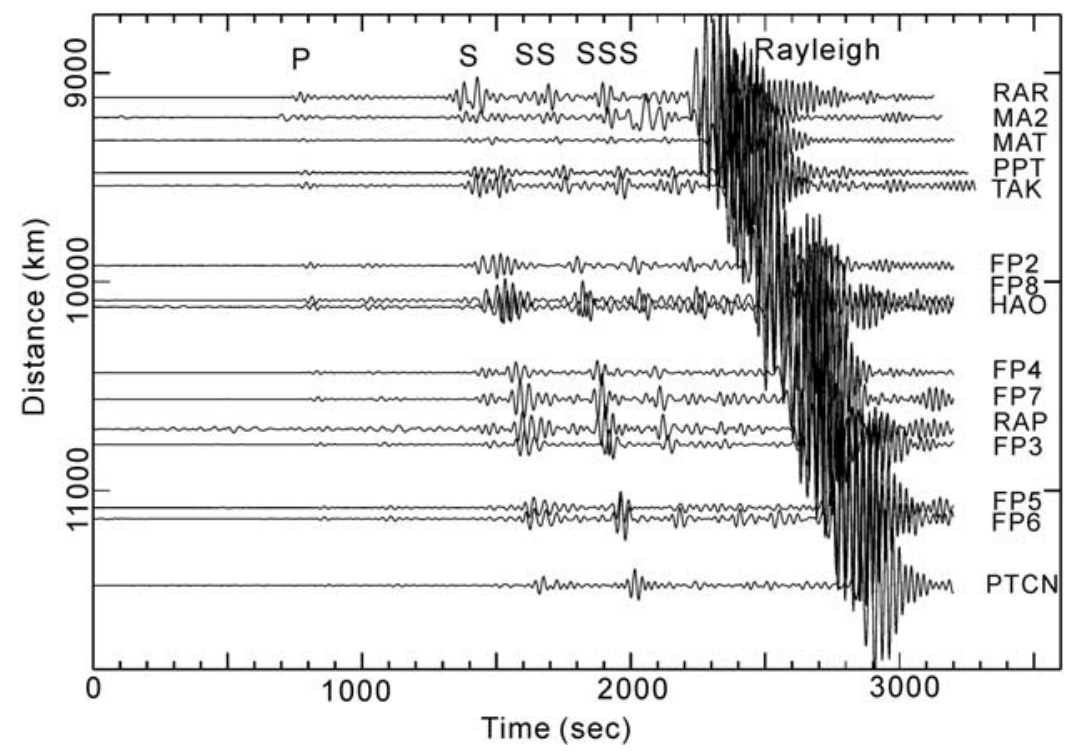

Figure 2. Vertical seismograms of a Japanese event (8 October 2003, Mw $=6.7$ ) recorded at the BBOBS, PLUME, and existing permanent broadband stations in the studied area. Stations whose names start with "FP" are located on seafloor, and the others are on oceanic islands. The vertical component records are filtered from $10 \mathrm{~s}$ to $50 \mathrm{~s}$. RAR and PTCN stations are IRIS (Incorporated Research Institutions for Seismology) stations, and PPT is a GEOSCOPE station.

waves have large long-period vertical motion. As an example, Figure 2 shows a vertical component record section band-pass filtered from 10 to $50 \mathrm{~s}$ for a Japanese event at the BBOBS, PLUME, and permanent broadband stations. Signal-to-noise ratios in this time range were comparable for both the island and seafloor stations, and for the temporary and permanent stations. In the present study we also used broadband data from permanent land-based stations (open triangles in Figures 3a, 3d, and 3g), 10 IRIS stations, 3 CEA (Commissariat à l'Energie Atomique) stations, 1 GEOSCOPE station, and 6 SPANET stations [Ishida et al., 1999].

\section{Upper Mantle}

[6] We determined the seismic velocity structure of the upper mantle down to $400 \mathrm{~km}$ by analyzing the period-dependent velocities (called dispersion) of waves traveling along the Earth's surface, whose energy is confined to the crust and the shallow parts of the mantle. The lateral resolution achieved by our observation was $400-500 \mathrm{~km}$, as shown below.

\subsection{Surface Wave Analysis: Two-Station Method}

[7] To resolve the slow velocities associated with mantle plumes, we employed the two-station method [Dziewonski and Hales, 1972; Isse et al.,
2006] when measuring surface wave dispersion. When two stations are located on approximately the same great circle from an earthquake, the phase velocity dispersion between them can be determined by computing the phase differences between the surface wave pairs. This method allows us to ignore the effects of phase shift due to source excitation and lateral heterogeneity far outside the station-to-station path. We selected two-station pairs that met the condition that the separation of the great circle paths to the stations was within the first Fresnel zone. We measured the phase velocity dispersion of the fundamental mode Rayleigh waves for periods of $40-140 \mathrm{~s}$. In this time span, the number of surface wave paths was 693-1201. We inverted the measured phase velocities between station pairs for 2-D phase velocity maps for periods of 40 to $140 \mathrm{~s}$ with a $10 \mathrm{~s}$ interval using the LSQR algorithm [Paige and Saunders, 1982]. The model space was parameterized using the B spline basis functions with an interval of $2^{\circ}$. We then inverted the dispersion for the $\mathrm{S}$ wave velocity model down to $400 \mathrm{~km}$ for each grid, using the theoretical relationship between the period dependence of surface waves and the depth variation of $\mathrm{S}$ waves. We used the iterative least squares scheme [Tarantola and Valette, 1982] for this inversion. Our reference 1-D model was PREM [Dziewonski and Anderson, 1981] except for the crust, for which we adopted the CRUST2.0 model [Bassin 
(a) Input
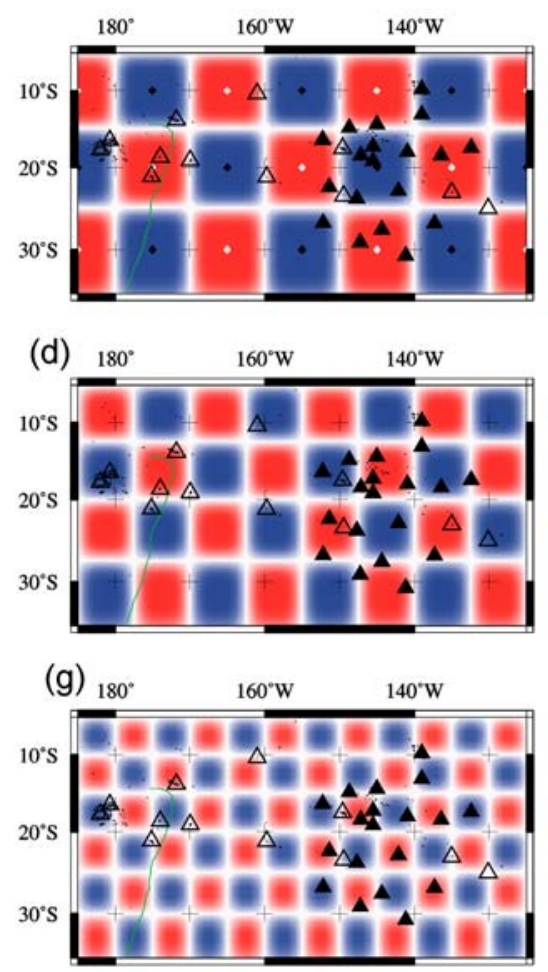

(b) Without BBOBS and PLUME

(c) With BBOBS and PLUME
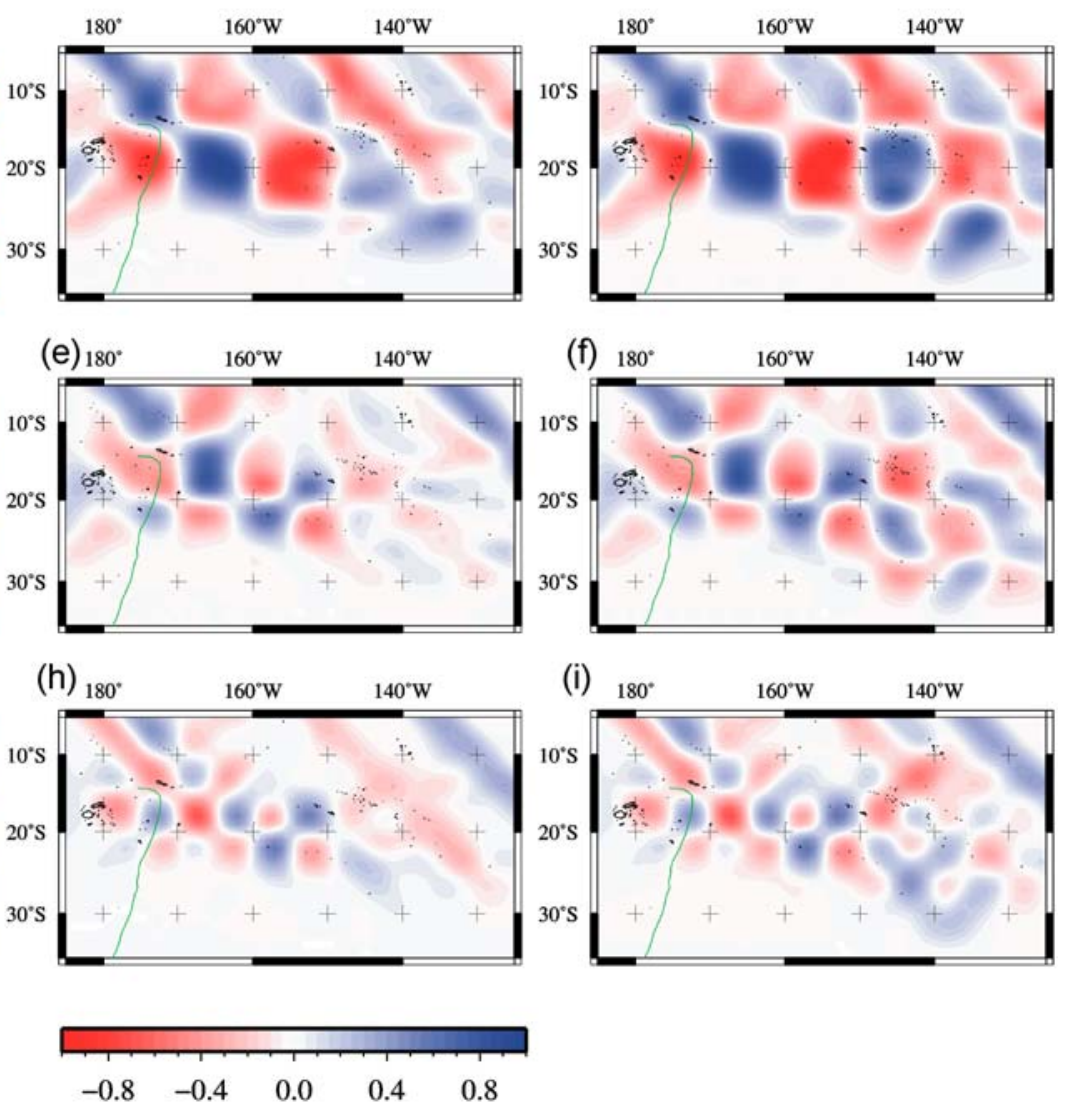

Figure 3. Checkerboard resolution test for surface wave tomography with $(\mathrm{a}-\mathrm{c}) 10^{\circ}$, (d-f) $7.5^{\circ}$, and $(\mathrm{g}-\mathrm{i}) 5^{\circ}$ cells at a period of $40 \mathrm{~s}$. Figures $3 \mathrm{a}, 3 \mathrm{~d}$, and $3 \mathrm{~g}$ show the input pattern. Figures $3 \mathrm{~b}, 3 \mathrm{e}$, and $3 \mathrm{~h}$ show the pattern recovered without using BBOBS and PLUME data. Figures 3c, 3f, and 3i show the pattern reconstructed using BBOBS and PLUME data. The solid triangles are the French Polynesian region where the temporary stations were installed. The open triangles in Figures 3a, 3d, and 3g denote permanent broadband stations, and the solid triangles are the BBOBS and PLUME stations.

et al., 2000]. See Isse et al. [2006] for further details.

[8] To observe how phase velocity distribution could be resolved by the present path coverage, we performed ray theoretical checkerboard resolution tests with cell sizes from $5^{\circ}$ to $10^{\circ}$ (Figure 3). The checkerboard pattern is well recovered, especially in the French Polynesia region where the major part of the superswell is located (Figures 3c, $3 \mathrm{f}$, and $3 \mathrm{i}$ ). If the temporary BBOBS and PLUME stations (solid triangles in Figures 3a, 3d, and 3g) are removed from this test, the resolvability is degraded, particularly in the eastern French Polynesia region (Figures $3 \mathrm{~b}, 3 \mathrm{e}$, and $3 \mathrm{~h}$ ). These features are common to all three cell sizes. Even though the temporary stations provided only $10-$ $15 \%$ of the total data, this made a substantial contribution to improving our tomographic image of the superswell. From the above assessment, we roughly estimated the lateral resolution to be about $500 \mathrm{~km}$ beneath the French Polynesian region.

\subsection{Localized Low-Velocity Anomalies}

[9] We will now discuss the lateral $\mathrm{S}$ velocity variation in the upper $200 \mathrm{~km}$, where it is best resolved by our data. The average $\mathrm{S}$ velocity profile beneath the South Pacific superswell (Figure 4b) closely resembles the velocity profile created from a global 3-D model [Masters et al., 2000] of similar seafloor ages, suggesting that the South Pacific upper mantle has no anomaly that is uniformly hot throughout. The 3-D S velocity variations are presented in Figures $4 \mathrm{c}-4 \mathrm{f}$ in a map view and in cross sections in Figures 5a and 5c. The dominant feature visible in Figure 4 is the cooling of the Pacific plate with age, as evidenced by the westward increase of velocities in the upper $100 \mathrm{~km}$ (Figures $4 \mathrm{c}$ and $4 d$ ). On shorter scales, we identify 

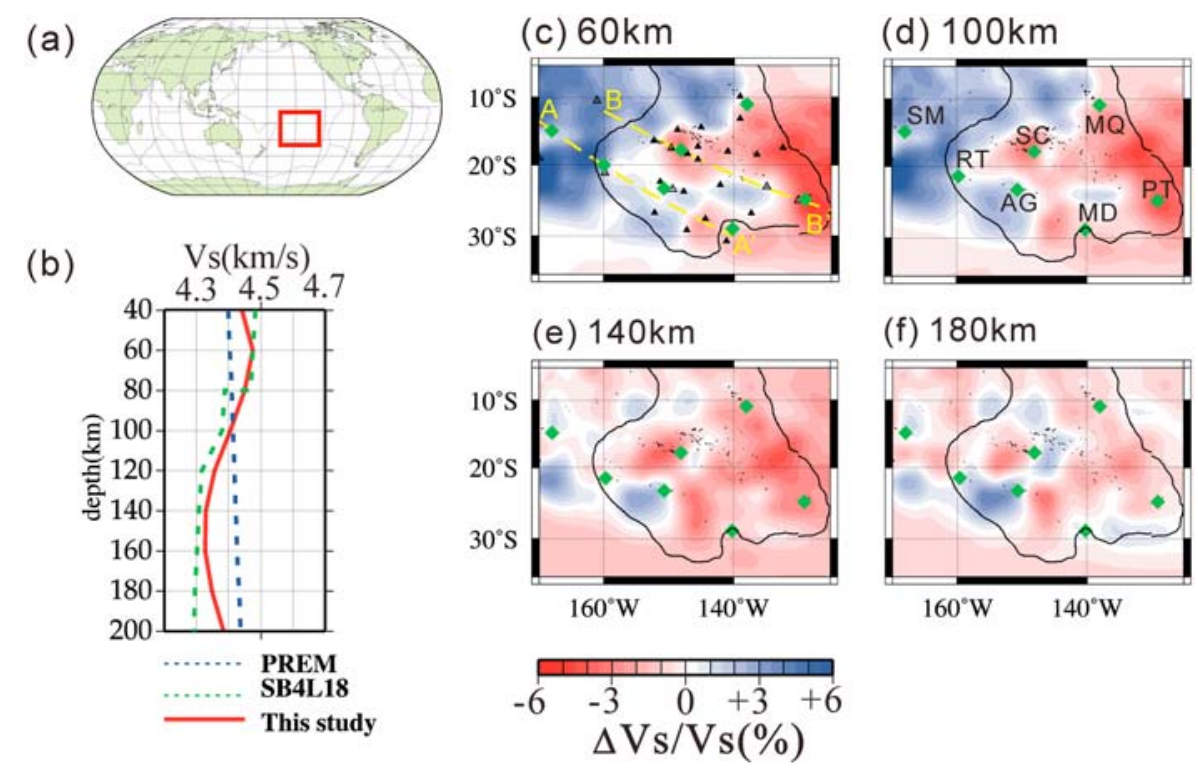

\section{(f) $180 \mathrm{~km}$}

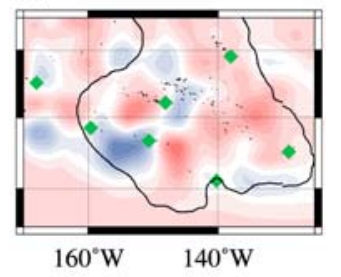

Figure 4. S wave velocity model in the upper mantle beneath the South Pacific. (a) Location of the studied region in the South Pacific. (b) Average S wave velocity profile obtained in the present study (in red) together with the average profile obtained by Masters et al. [2000] in the northern Pacific for 24-112 Myr of seafloor age (in green), which are the same ages as in the studied region and the preliminary reference earth model (PREM, blue). Lateral variation in S wave velocity at depths of (c) 60, (d) 100, (e) 140, and (f) $180 \mathrm{~km}$. Deviations from the average 1-D structure beneath the Pacific Ocean synthesized from a global 3-D model [Masters et al., 2000] are shown. Green diamonds are active hot spots. Two-letter labels on the diamonds are the abbreviated names of the hot spots: SM, Samoa; RT, Rarotonga; SC, Society; AG, Arago; MD, Macdonald; MQ, Marquesas; PT, Pitcairn. The solid curve indicates the superswell region defined by anomalous seafloor uplift greater than $300 \mathrm{~m}$. Black triangles in Figure $4 \mathrm{c}$ denote temporary PLUME or BBOBS stations. Curves A- $\mathrm{A}^{\prime}$ and $\mathrm{B}^{-\mathrm{B}^{\prime}}$ in Figure $4 \mathrm{c}$ indicate locations of cross section shown in Figure 5.
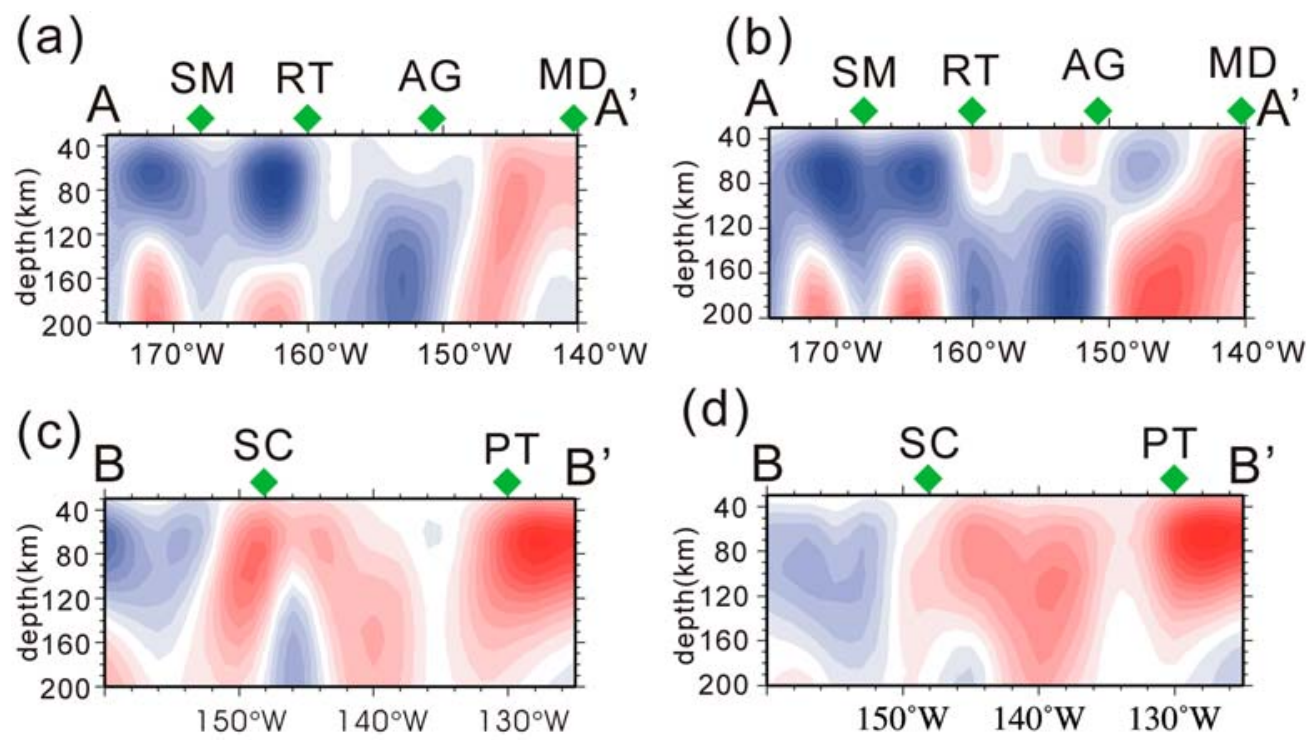

(d)

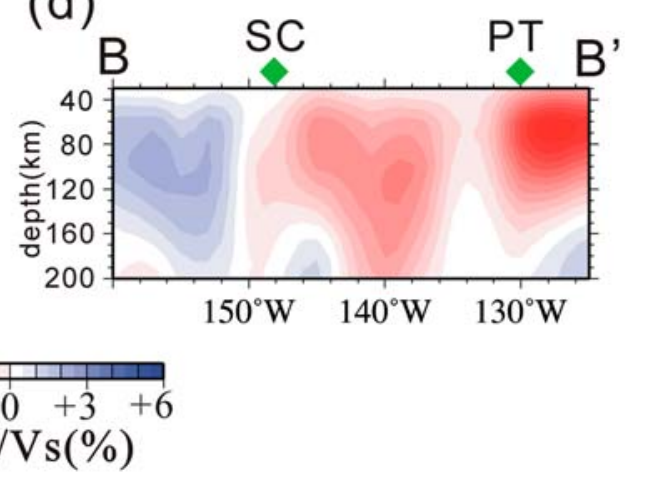

Figure 5. Upper mantle cross sections of $\mathrm{S}$ wave velocity anomalies along ( $\mathrm{a}$ and $\mathrm{b}$ ) the $\mathrm{A}-\mathrm{A}^{\prime}$ profile (from the Samoa hot spot to the Cook-Austral chain) and (c and d) the B-B' profile (crossing the Society and the Pitcairn hot spots). Figures $5 \mathrm{a}$ and $5 \mathrm{c}$ are obtained by the present study, and Figures $5 \mathrm{~b}$ and $5 \mathrm{~d}$ are by Isse et al. [2006], i.e.,

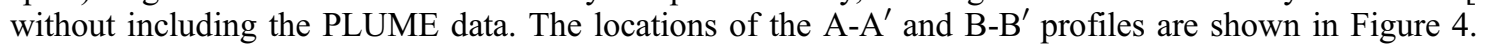


slow anomalies of about $2-3 \%$ near the Society, Macdonald, Pitcairn and Marquesas hot spots at depths down to $200 \mathrm{~km}$, while the anomalies in the vicinity of the Macdonald hot spot are located 200-300 km northwest of the hot spot. Velocities beneath the Samoa, Rarotonga, and Arago hot spots are close to the average velocities in the studied area, but slightly slower than those in the surrounding regions at depths shallower than $100 \mathrm{~km}$ (Figures $4 \mathrm{c}$ and $5 \mathrm{a}$ ). The slow anomalies beneath the South Pacific hot spots are not necessarily vertical. For instance, the slow anomaly near the Macdonald hot spot appears to shift northwestward as it increases in depth.

[10] Isse et al. [2006] determined upper mantle S velocity anomalies using data from the BBOBS stations and the permanent land stations (IRIS, GEOSCOPE, CEA, and SPANET), but without including the PLUME data. Figure 5 compares the $\mathrm{S}$ velocity cross sections obtained by the present study and by Isse et al. [2006]. The slow anomalies obtained in the present study have narrower widths (about $500 \mathrm{~km}$ in diameter) beneath the Society and Macdonald hot spots than those obtained by Isse et al. [2006], indicating an improved lateral resolution due to the present study's inclusion of PLUME data. In the present study, two slow anomalies were found beneath the Society hot spot. One is located around $150^{\circ} \mathrm{W}$ and the other around $145^{\circ} \mathrm{W}-150^{\circ} \mathrm{W}$ (Figure $5 \mathrm{c}$ ). The western anomaly was not resolved by Isse et al. [2006] (Figure 5d), probably because no BBOBS stations were deployed west of the Society hot spot. The most recent Pacific-scale $\mathrm{S}$ velocity models [Maggi et al., 2006a, 2006b] obtained by surface wave tomography using land-based data, including PLUME data (but without the BBOBS data), also showed deep-rooted low velocities beneath the Society and Macdonald hot spots, but only superficially rooted $(<150 \mathrm{~km})$ low velocities beneath the Marquesas. The low velocity anomalies given by Maggi et al. [2006a] have widths of $700-1000 \mathrm{~km}$ in diameter, which are broader than those found in the present study. This difference is probably due to the difference in lateral resolution: about $800 \mathrm{~km}$ in the study by Maggi et al. [2006a] and $500 \mathrm{~km}$ in the present study.

[11] In summary, by combining the data from the permanent and temporary (land and seafloor) networks, we found slow anomalies beneath the South Pacific hot spots that could represent narrow plumes in the upper mantle. The average $\mathrm{S}$ velocity profile beneath the South Pacific superswell is close to that of other oceanic regions whose seafloor is of a similar age, suggesting that the slow anomalies are localized. This upper mantle surface wave tomography study indicates that slow anomalies near the Society, Macdonald and Pitcairn hot spots may be rooted at depths of $150-200 \mathrm{~km}$ or greater.

\section{Mantle Transition Zone}

[12] The mantle transition zone (MTZ) is defined as a layer bounded by two seismic discontinuities: the $410 \mathrm{~km}$ and $660 \mathrm{~km}$ discontinuities (called " 410 " and "660," respectively). The MTZ forms a transition layer between the upper mantle and the lower mantle. These discontinuities are now broadly accepted as representing the mineral phase transition from olivine in the upper mantle to wadsleyite and ringwoodite in the transition zone, and to perovskite plus magnesiowüstite in the lower mantle [e.g., Helffrich, 2000]. Because these phase transitions are pressure- and temperature-dependent and have opposite Clapeyron slopes for the " 410 " and " 660 ," determining the depths of the two discontinuities provides indirect information regarding the temperature anomaly within the MTZ [e.g., Irifune et al., 1998; Katsura et al., 2004]. For instance, if a hot plume ascends from the lower to the upper mantle, the MTZ should be thinner than normal, since the " 410 " and " 660 " are caused by exothermic (positive Clapeyron slope) and endothermic (negative Clapeyron slope) phase transformations, respectively, whose transformation depths are controlled by the temperature. In the present study, after the depths of the " $410 "$ and " 660 " beneath the stations were estimated by the receiver function method [Langston, 1977; Owens and Crosson, 1988], they were then used to determine the MTZ thickness.

[13] Previous studies have already focused on the French Polynesia MTZ. Using SS waves underside reflections from the "410" and "660," Niu et al. [2002] determined the MTZ thickness with a spatial resolution of $1000 \mathrm{~km}$ and observed a thinned transition zone beneath the Society hot spot. The work by Suetsugu et al. [2007] determined the MTZ thickness from only the BBOBS data, which did not allow them to determine the MTZ thickness beneath most of the hot spot themselves, due to the great distance between the BBOBS stations and the hot spots. In order to present an updated map of the MTZ thickness beneath all of French Polynesia, we therefore applied receiver function analysis to the PLUME data in order to add more complete information to the previously published results. The spatial resolution achieved by the present study was about 
(a) Receiver functions

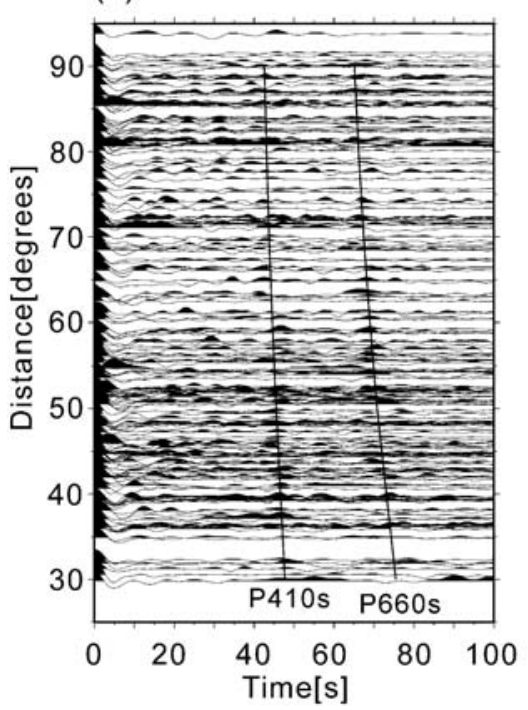

(b) Depth-converted stacks

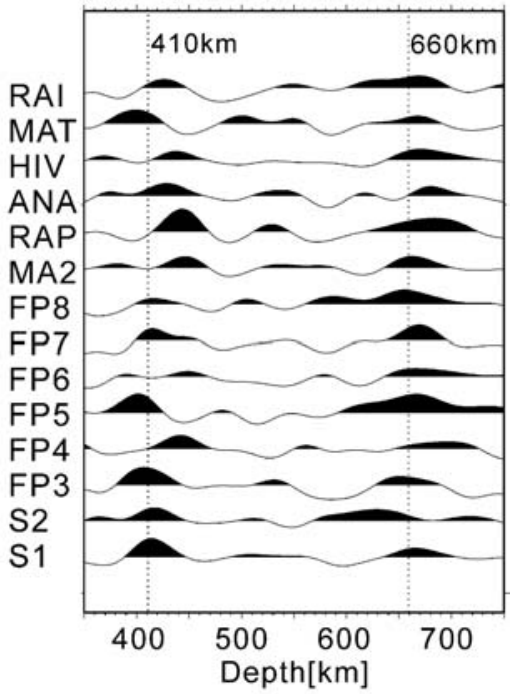

Figure 6. (a) Record sections of all the receiver functions obtained by the present study. $\mathrm{P}$ wave arrivals are aligned to $0 \mathrm{~s}$. Theoretical traveltimes of P410s and P660s obtained from the IASP91 model. (b) Stacked and depth-converted receiver functions for each station. In the plot, depth conversion is performed using the IASP91 model, while the depths plotted in Figure 6 are obtained using a 3-D velocity model.

$300 \mathrm{~km}$, which enabled us to detect narrow plumes in the MTZ.

\subsection{Receiver Function Method}

[14] The aim of the receiver function method is to detect the arrival of secondary seismic phases generated at seismic interfaces. In this work, we focused on the S waves generated at the "410" and "660" from an incident P wave. We first equalized the source effect and extract Ps waves, then computed a receiver function by deconvolving a radial component record with its vertical component for each event at each station. We used a band-pass filter with corner periods of 8 and $50 \mathrm{~s}$ to suppress long-period oceanic noises observed in the horizontal component records. We corrected for the attenuation in the deconvolution. We plotted all receiver functions used in the current study, as well as the theoretical Ps time curves expected for conversion depths of the "410" and "660," as shown in Figure 6a. The peak alignments of the receiver functions appear near the expected P410s and P660s curves, though they are generally not large enough to be analyzed individually.

[15] Next, we employed the VSS method [Gurrola et al., 1994; Saita et al., 2002; Suetsugu et al., 2005 b] for stacking receiver functions, as shown in Figure $6 a$, to constrain the " $410 "$ and " 660 " depths, in which the effect of lateral velocity variation beneath the studied area could be easily accounted for. The moveout correction was com- puted for discontinuity depths from 0 to $800 \mathrm{~km}$, and for $\mathrm{S}$ velocities perturbed from $-2.5 \%$ to $+2.5 \%$, with respect to the IASP91 model [Kennett and Engdahl, 1991]. We relied on existing 3-D shear velocity models to obtain the average $\mathrm{S}$ velocity perturbations beneath the stations, which were used to correct the depths and the MTZ thickness to account for the effects of lateral velocity variation. We used CRUST2.0 for the crustal correction, and a global shear velocity model S20RTS [Ritsema and van Heijst, 2000] for the depth range from the Moho to $660 \mathrm{~km}$. Confidence levels for the discontinuity depths were computed using the bootstrap method [Efron and Tibshirani, 1986], which randomly resamples the receiver functions 500 times prior to stacking. See Suetsugu et al. [2005b] for further details.

[16] In the present paper, we choose to address the MTZ thickness rather than the "410" and "660" depths, because it is less affected by the velocity structures of the strongly heterogeneous upper mantle (above the "410"). Since the Fresnel zone of P410s and P660s waves at periods of $8-50 \mathrm{~s}$ is about $300 \mathrm{~km}$ in diameter, we used this value to represent the spatial resolution of the lateral variation of the MTZ thickness.

\subsection{Localized Thin MTZ Beneath Hot Spots}

[17] The stacked depth-converted receiver functions are presented in Figure 6b, and the obtained depths 
Table 1. Station Coordinates, Depths of the "410" and "660," and the MTZ Thickness in the South Pacific Superswell

\begin{tabular}{|c|c|c|c|c|c|c|c|c|}
\hline $\begin{array}{l}\text { Station } \\
\text { Code }\end{array}$ & $\begin{array}{l}\text { Latitude } \\
\left({ }^{\circ} \mathrm{S}\right)\end{array}$ & $\begin{array}{l}\text { Longitude } \\
\left({ }^{\circ} \mathrm{W}\right)\end{array}$ & $\begin{array}{c}\text { Seafloor } \\
\text { Depth } \\
\text { (m) }\end{array}$ & $\begin{array}{l}\text { “410” } \\
(\mathrm{km})\end{array}$ & $\begin{array}{l}\text { “660” } \\
(\mathrm{km})\end{array}$ & $\begin{array}{c}\text { MTZ } \\
\text { Thickness } \\
(\mathrm{km})\end{array}$ & $\begin{array}{l}\text { Number of } \\
\text { Data Sets }\end{array}$ & Reference \\
\hline S1 & 18.411 & 147.158 & 4472 & $419 \pm 8$ & $665 \pm 13$ & $247 \pm 16$ & 16 & Suetsugu et al. [2007] \\
\hline $\mathrm{S} 2$ & 19.190 & 145.516 & 4493 & $415 \pm 14$ & $631 \pm 16$ & $216 \pm 19$ & 12 & Suetsugu et al. [2007] \\
\hline FP2 & 13.143 & 139.035 & 3850 & - & - & - & - & Suetsugu et al. [2007] \\
\hline FP3 & 17.485 & 132.440 & 4380 & $409 \pm 8$ & $656 \pm 14$ & $247 \pm 14$ & 19 & Suetsugu et al. [2007] \\
\hline FP4 & 22.895 & 142.128 & 4730 & $442 \pm 11$ & $680 \pm 16$ & $238 \pm 15$ & 12 & Suetsugu et al. [2007] \\
\hline FP5 & 26.895 & 137.304 & 4350 & $402 \pm 5$ & $658 \pm 12$ & $257 \pm 12$ & 14 & Suetsugu et al. [2007] \\
\hline FP6 & 30.694 & 141.133 & 4400 & - & $662 \pm 11$ & - & 14 & Suetsugu et al. [2007] \\
\hline FP7 & 29.129 & 147.191 & 4750 & $420 \pm 8$ & $669 \pm 8$ & $249 \pm 12$ & 16 & Suetsugu et al. [2007] \\
\hline FP8 & 26.833 & 152.219 & 4930 & - & $654 \pm 16$ & - & 11 & Suetsugu et al. [2007] \\
\hline ANA & 17.354 & 145.505 & - & $433 \pm 11$ & $676 \pm 10$ & $243 \pm 14$ & 17 & This study \\
\hline $\mathrm{HAO}$ & 18.058 & 140.957 & - & - & $668 \pm 18$ & - & 28 & This study \\
\hline HIV & 9.759 & 139.004 & - & $435 \pm 14$ & $670 \pm 8$ & $235 \pm 16$ & 42 & This study \\
\hline MA2 & 16.443 & 152.274 & - & $446 \pm 13$ & $665 \pm 3$ & $219 \pm 14$ & 23 & This study \\
\hline MAT & 14.869 & 148.707 & - & $400 \pm 6$ & $664 \pm 10$ & $264 \pm 9$ & 23 & This study \\
\hline RAI & 23.873 & 147.685 & - & $430 \pm 6$ & $668 \pm 9$ & $238 \pm 10$ & 14 & This study \\
\hline RAP & 27.618 & 144.334 & - & $444 \pm 2$ & $671 \pm 16$ & $227 \pm 17$ & 12 & This study \\
\hline REA & 18.458 & 136.440 & - & - & $676 \pm 7$ & - & 18 & This study \\
\hline RUR & 22.426 & 151.368 & - & - & $684 \pm 5$ & - & 14 & This study \\
\hline TAK & 14.471 & 145.036 & - & $448 \pm 10$ & - & - & 19 & This study \\
\hline TBI & 23.349 & 149.461 & - & - & - & $249 \pm 4$ & 61 & Suetsugu et al. [2004] \\
\hline PPT & 17.569 & 149.576 & - & - & - & $236 \pm 9$ & 59 & Suetsugu et al. [2004] \\
\hline RKT & 23.118 & 134.972 & - & - & - & $245 \pm 13$ & 32 & Suetsugu et al. [2004] \\
\hline PTCN & 25.073 & 130.095 & - & - & - & $225 \pm 9$ & 18 & Suetsugu et al. [2004] \\
\hline
\end{tabular}

of the "410" and "660" are listed in Table 1 . The average MTZ thickness beneath the South Pacific $(240 \mathrm{~km})$ is close to the global average of $241-243$ km [Flanagan and Shearer, 1998; Gu et al., 1998], suggesting that the average temperature in the MTZ beneath the South Pacific is normal. As shown in Figure 7a, the MTZ thickness values beneath most of the stations are nearly normal, taking into account uncertainties of 9-19 km. Notable exceptions are the thinned MTZ beneath two stations near the Society hot spot, with a thickness of $216 \mathrm{~km}$ at S2, and $219 \mathrm{~km}$ at MA2 (see Figure 1 for station codes and locations), which suggest that hot plumes may be ascending to this hot spot from the lower mantle. Temperature anomalies are estimated to be 150-200 $\mathrm{K}$, assuming the experimentally determined Clapeyron slope of the phase transformations [Irifune et al., 1998; Katsura et al., 2004]. The ANA, MAT, PPT, S1, and FP4 stations, which surround S2 and MA2, do not show such a thin MTZ. Considering the spacing of these stations, the hot anomalies in the MTZ are $300-400 \mathrm{~km}$ in diameter, which represents a narrow plume in the MTZ. The stations near the Macdonald and Pitcairn hot spots may also have a thin MTZ beneath them $(227 \mathrm{~km}$ at RAP and $225 \mathrm{~km}$ at PTCN, respectively). The MTZ thickness beneath the Marquesas and Arago hot spots is close to the global average, which suggests that no hot plumes ascend to these hot spots from the lower mantle.

[18] Suetsugu et al. [2007] determined the MTZ thickness beneath the BBOBS and the permanent land stations in the South Pacific superswell (Figure $7 \mathrm{~b}$ ), which are also included in Figure $7 \mathrm{a}$ and Table 1. They could not determine the MTZ thickness beneath most of the hot spot chains in the studied region (e.g., the Cook-Austral, northwestern Society, and Marquesas chains) because most of the BBOBS stations are located away from the island chains. The thin MTZ beneath the region northwest of the Society hot spot (MA2) and west of the Macdonald hot spot (RAP), and the normal MTZ thickness beneath the Marquesas (HIV) hot spot, are estimates that are based upon the PLUME data alone. This highlights the fact that both on-land and ocean bottom seismic stations are necessary in order to accurately and thoroughly determine thickness variations in the MTZ in complex oceanic environments, such as the South Pacific area. Niu et al. [2002] analyzed differential traveltimes between SS and its underside reflections from the " 410 " and "660" beneath the South Pacific Superswell. The average MTZ thickness beneath the Superswell region is $237 \mathrm{~km}$, which is close to the average value of $240 \mathrm{~km}$ found in the present study. They 


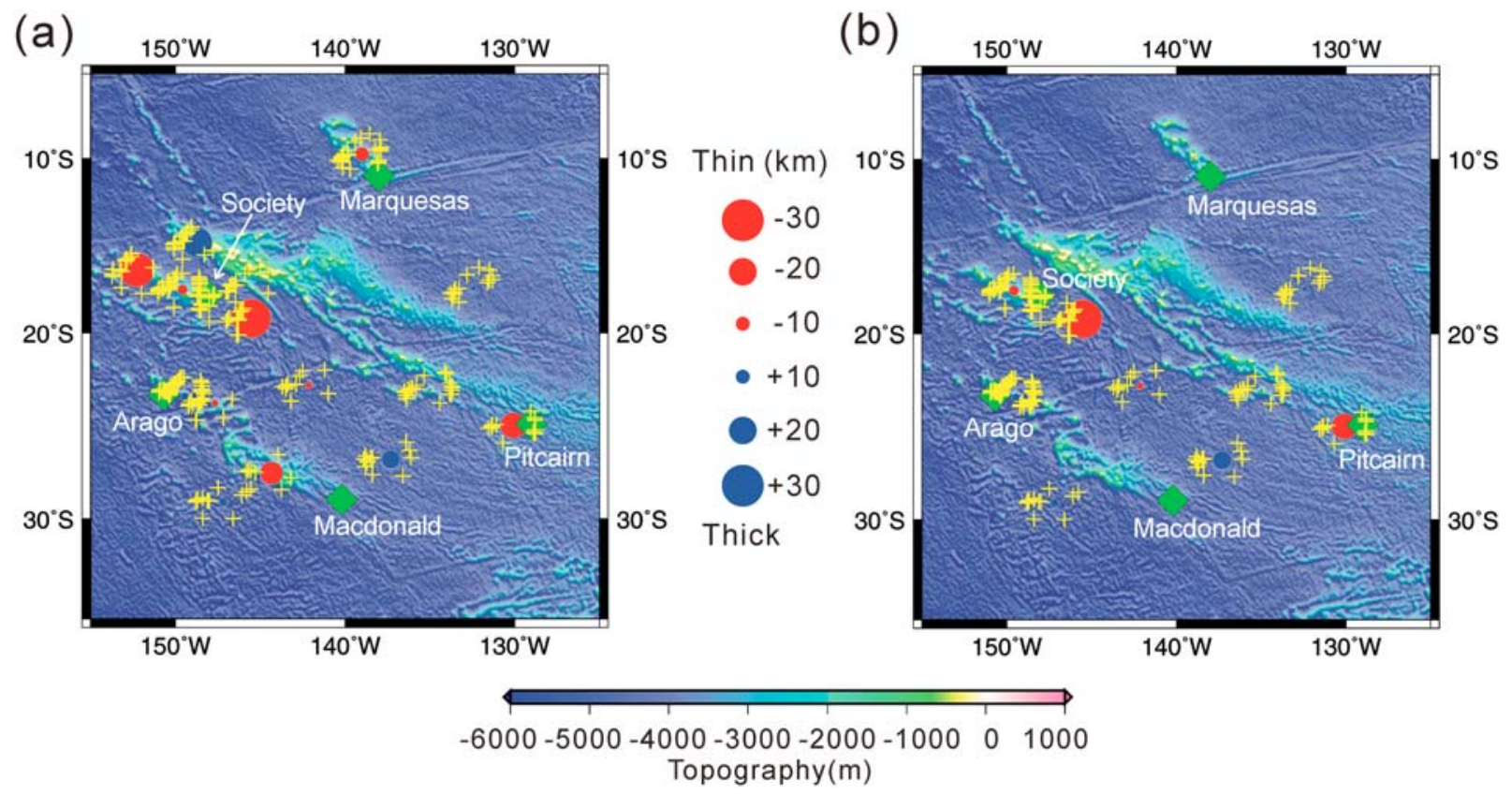

Figure 7. Maps showing the MTZ thickness obtained (a) by this study, i.e., using permanent, BBOBS, and PLUME data, and (b) by Suetsugu et al. [2007], i.e., without the PLUME stations. The deviation from the global average [Flanagan and Shearer, 1998] is shown. Yellow plus signs are the P to S conversion points at the "410." Red and blue symbols denote the MTZ thinner and thicker than average, respectively. Green diamonds are active hot spots.

found that the MTZ is about $30 \mathrm{~km}$ thinner locally beneath the Society hot spot than the global average, a finding that is consistent with the $25 \mathrm{~km}$ thinner MTZ beneath S2 that was found in the present study. The MTZ is not thinned beneath the other hot spots in the superswell area, while the coverage of the SS precursors is more limited around the other hot spots than around the Society hot spot.

\section{Lower Mantle}

[19] Body waves observed at distances greater than $3000 \mathrm{~km}$ dive into the lower mantle, and for this reason present a suitable avenue for exploring it. In the present study, we used a body wave tomography technique to analyze the lower mantle structure, to test for the presence of a large-scale low velocity body that could correspond to the South Pacific superplume, and to examine whether or not hot anomalies seen in the upper mantle and in the MTZ could originate in the lower mantle.

\subsection{P Wave Traveltime Tomography}

[20] We obtained $\mathrm{P}$ waveforms of 121 earthquakes that took place from 2003 to 2005 for our P wave traveltime measurements. Hypocenter information was obtained from the United States Geological Survey's Earthquake Data Reports. A two-pole
Butterworth filter with cutoff frequencies of 0.03 and $0.08 \mathrm{~Hz}$ (equivalent to periods of 13 to $33 \mathrm{~s}$ ) was applied to the observed broadband seismographs, because a low noise level was recognized in this frequency range. We measured relative traveltimes by a cross-correlation method, which yielded 1356 independent measurements that have correlation coefficients larger than 0.7. See Tanaka et al. [2009a] for a detailed description of traveltime measurement. We used the traveltimes that we measured together with the 121 reference times in order to make further analyses. In total, we used 1477 residuals composed from the relative traveltimes and reference times, as well as the ISC P wave arrival time data for global mantle ray theoretical tomography [Fukao et al., 2003]. Ellipticity corrections [Kennett and Gudmundsson, 1996] were applied to all data sets. BBOBS and PLUME data were assigned ten times the weight of those assigned to the ISC catalog so that the large volume of ISC data did not overwhelm the contribution of BBOBS and PLUME data to the obtained seismic image.

[21] The block size of the velocity model was automatically adjusted according to the $\mathrm{P}$ wave path coverage; the block size beneath the South Pacific is $1.4^{\circ}$ laterally and $200 \mathrm{~km}$ vertically. The checkerboard resolution test is presented in Figure 8. Note 
(a) Input Pattern
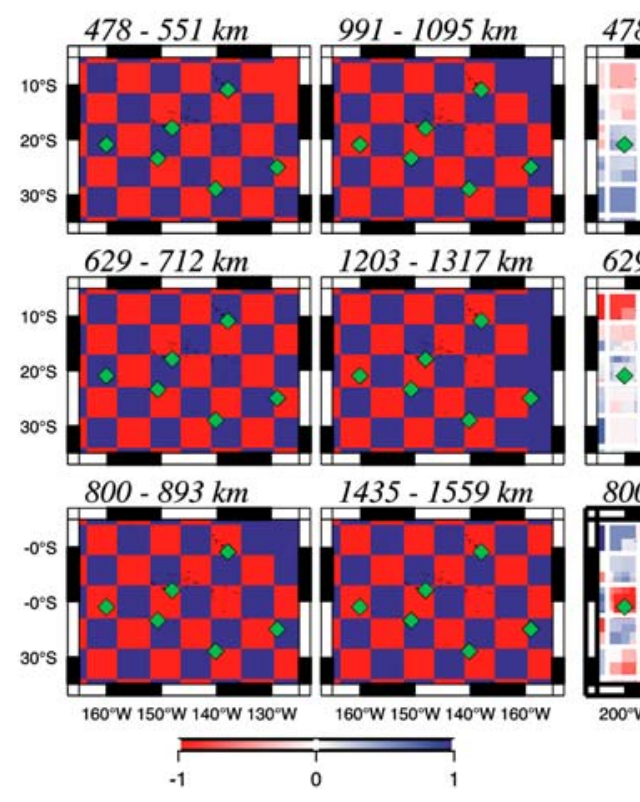

(c) ISC Data Only
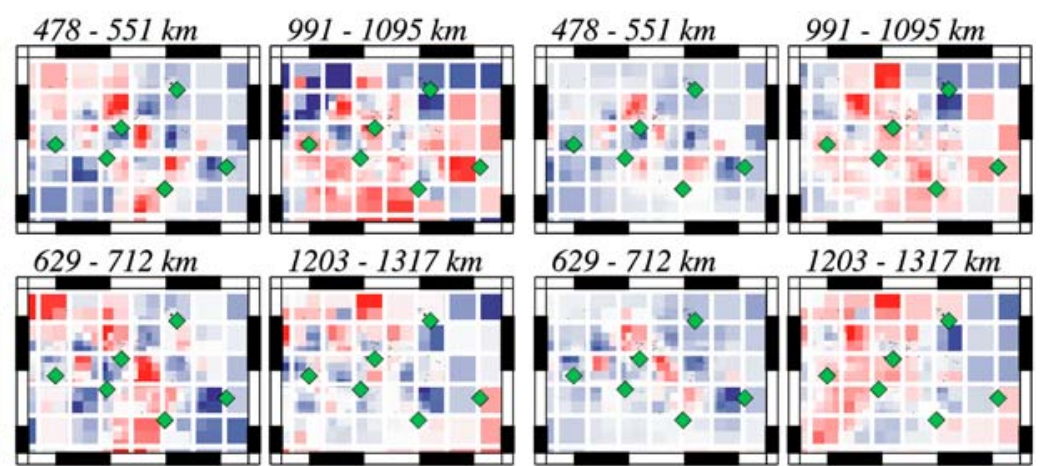

$800-893 \mathrm{~km}$

$1435-1559 \mathrm{~km}$
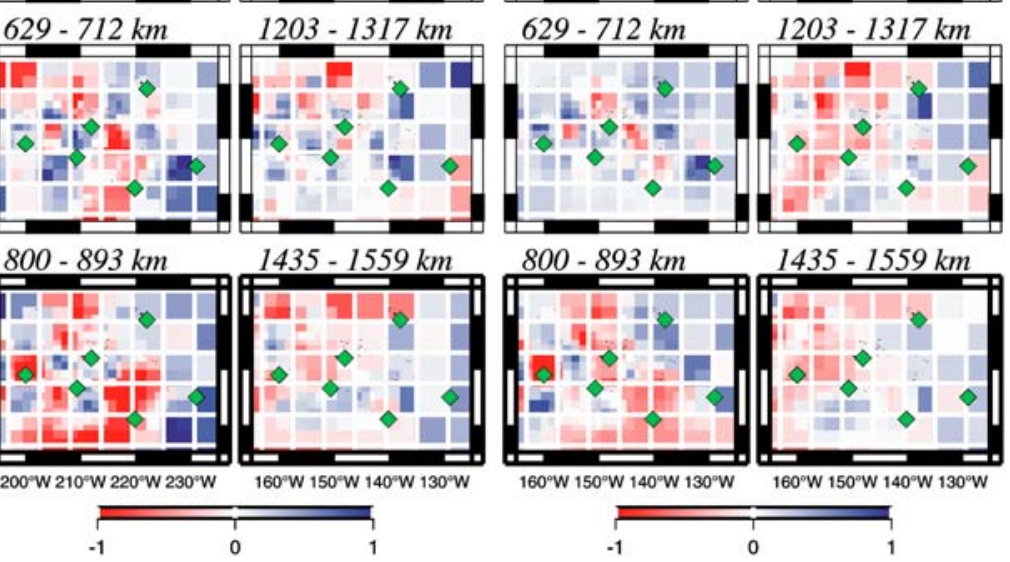

$800-893 \mathrm{~km}$ $1435-1559 \mathrm{~km}$

Figure 8. Checkerboard resolution test for the $\mathrm{P}$ wave traveltime tomography. Depths are shown at the top of each plot. Green diamonds are active hot spots. (a) Input pattern, (b) checkerboard recovered using all the data including PLUME and BBOBS data, and (c) checkerboard recovered using only the ISC data. The amplitude is normalized to that of the input anomaly.

that the resolution is substantially improved from the lower MTZ to the middle-lower mantle by taking into account both PLUME and BBOBS data sets. The spatial resolution in the lower mantle that was achieved by our calculations is estimated to be $\sim 500 \mathrm{~km}$. The resolution in the MTZ and upper mantle is much lower, which prevents us from obtaining well-resolved images above the "660."

\subsection{Large-Scale Low-Velocity Anomalies in the Middle-Lower Mantle}

[22] Low velocity anomalies are found throughout the lower mantle beneath the superswell, while the lateral dimension of the anomalies changes drastically at a depth of $1000 \mathrm{~km}$ (Figure 9). Below 1000 $\mathrm{km}$, slow anomalies of $1 \%$ are as large as $3000 \mathrm{~km}$ $\times 3000 \mathrm{~km}$, an area that previous studies referred to as the South Pacific superplume [Zhao, 2004; Mégnin and Romanowicz, 2000]. These anomalies seem continuous down to the core-mantle boundary. On the other hand, above $1000 \mathrm{~km}$, the slow anomalies split into narrower and more localized anomalies a few hundred kilometers in diameter.

[23] A comparison of $\mathrm{P}$ wave velocity maps obtained from only the ISC data, and from all data including the BBOBS and PLUME data, is presented in Figure 10. This comparison clearly illus- trates that the lateral dimension of the low-velocity anomalies in the tomographic model obtained from all the data abruptly becomes smaller above a depth of $1000 \mathrm{~km}$. The lateral dimension obtained from the ISC data only, does not change from a depth of $1200 \mathrm{~km}$ to $600 \mathrm{~km}$, which suggests a lack of resolution in the upper part of the lower mantle in the ISC-derived model. The apparent vertical continuity of the slow anomalies imaged from the ISC data could be due to insufficient spatial resolution that blurs the abrupt change in the lateral size of slow anomalies at a depth of $1000 \mathrm{~km}$. Regional seismic networks such as the BBOBS and PLUME stations are essential to the imaging of the superplume and narrow plumes. A large-scale low velocity anomaly was found by Tanaka et al. [2009a, 2009b], who used the BBOBS and PLUME data for regional $\mathrm{P}$ and $\mathrm{S}$ wave traveltime tomography. They showed that large-scale (about $1000 \mathrm{~km}$ in diameter) slow anomalies of $-2 \%$ for $\mathrm{P}$ velocity and $-4 \%$ for $S$ velocity culminate at a depth of $600-$ $1000 \mathrm{~km}$. Considering the vertical block size of 400 $\mathrm{km}$ used by Tanaka et al. [2009a, 2009b], their results are consistent with those in the present study. Tanaka et al. [2009a] also performed global $\mathrm{P}$ wave traveltime tomography using the BBOBS, PLUME, and ISC data, in addition to regional tomography. Their global model showed a large-scale slow anomaly at depths greater than $1000 \mathrm{~km}$ beneath 
(a) $629-712 \mathrm{~km}$

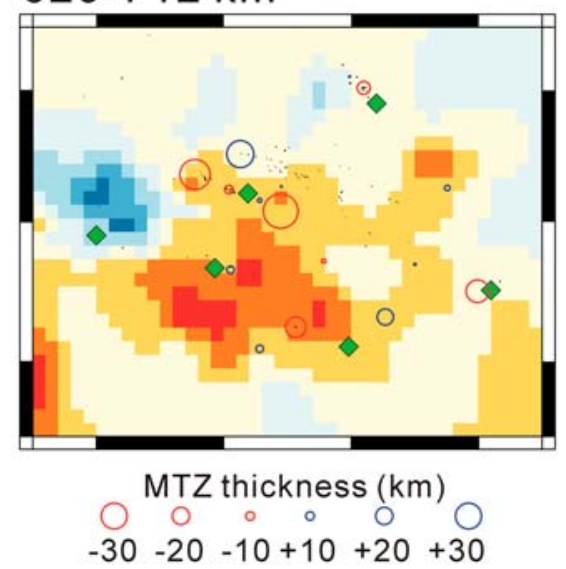

(c) $1095-1203 \mathrm{~km}$

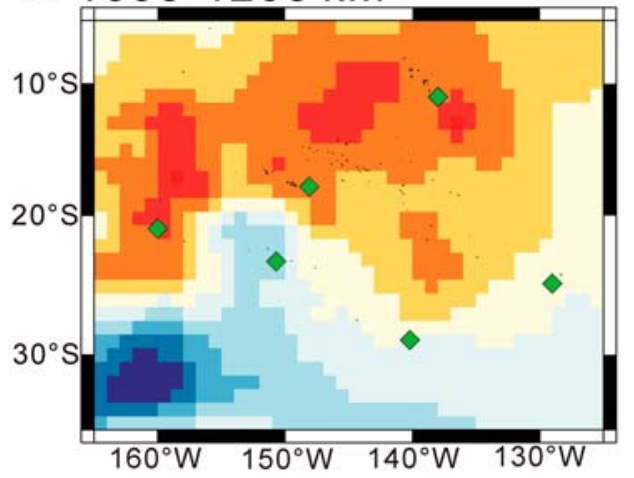

(b)

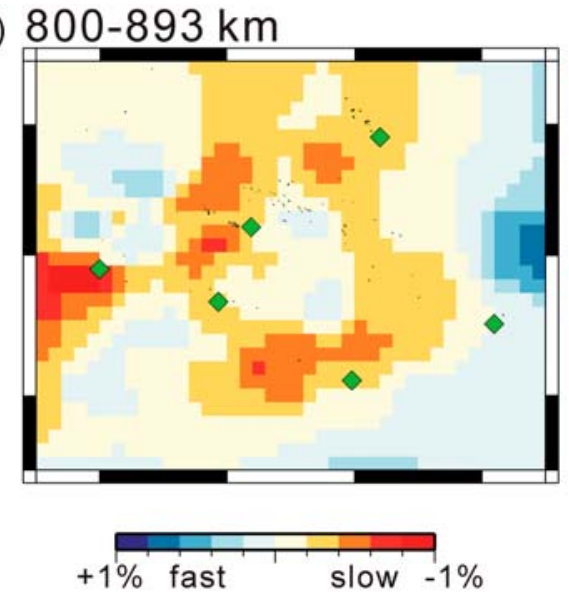

(d) $1317-1435 \mathrm{~km}$

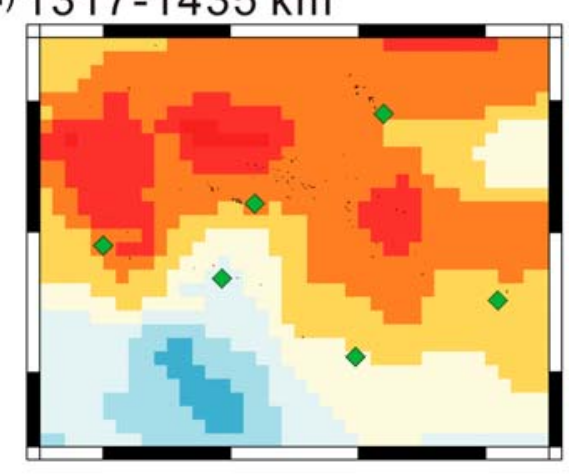

Figure 9. Map showing lateral variation in $\mathrm{P}$ wave velocity in the lower mantle at depths of (a) 629-712 km, (b) $800-893 \mathrm{~km}$, (c) $1095-1203 \mathrm{~km}$, and (d) $1317-1435 \mathrm{~km}$. Deviations from average 1-D structure beneath the Pacific Ocean are shown. Circles in Figure 9a are the MTZ thickness, where red and blue represent thicker and thinner than the global average, respectively, and the size is proportional to the deviation from the average. Green diamonds denote active hot spots.

the South Pacific superswell, as was observed in the present study. However, they used a fixed block size of $5^{\circ}$ and could not obtain clear images of the localized slow anomalies (a few hundred kilometers wide) at the top of the lower mantle, images that were obtained by the present study (Figures 9 and 10), since they did not fully utilize the data's potential to resolve fine heterogeneities.

\section{Discussion and Conclusions}

[24] Previous global tomographic studies have provided various images of mantle plumes beneath the South Pacific. Zhao [2004] obtained a large-scale low velocity anomaly throughout the mantle by employing ray theoretical traveltime inversion of ISC P arrival time data. Montelli et al. [2006] showed conduit-like low velocity anomalies throughout the mantle by means of finite frequency traveltime tomography [Dahlen et al., 2000], which are generated from broad low velocity anomalies at the core-mantle boundary. Takeuchi [2007, 2009] obtained a similar image through waveform inversion of long-period transverse records. Mégnin and Romanowicz [2000] and Romanowicz and Gung [2002] documented a large, low, dome-like velocity anomaly that culminates in the middle-lower mantle. Among previous studies, this finding was most consistent with the present study, though they posited a deeper location of the dome-like anomaly than does the present study. The continuous plume images in some of the previous studies may be due to a lack of regional data, as shown in Figure 10.

[25] In the composite Figure 11, the vertical profiles of the $\mathrm{P}$ wave tomograms in the lower mantle are presented together with those of the upper mantle S wave tomogram and the MTZ thickness. These cross sections suggest that narrow slow anomalies may be connected to the top surface of the superplume. These narrow anomalies are smaller than the spatial resolution of the lower 
(a) ISC, PLUME, BBOBS
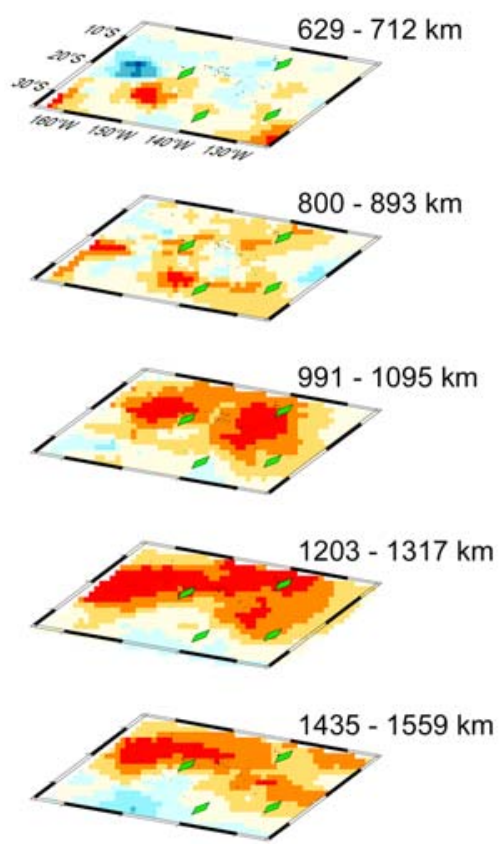

slow $1.0 \%$ (b) ISC only
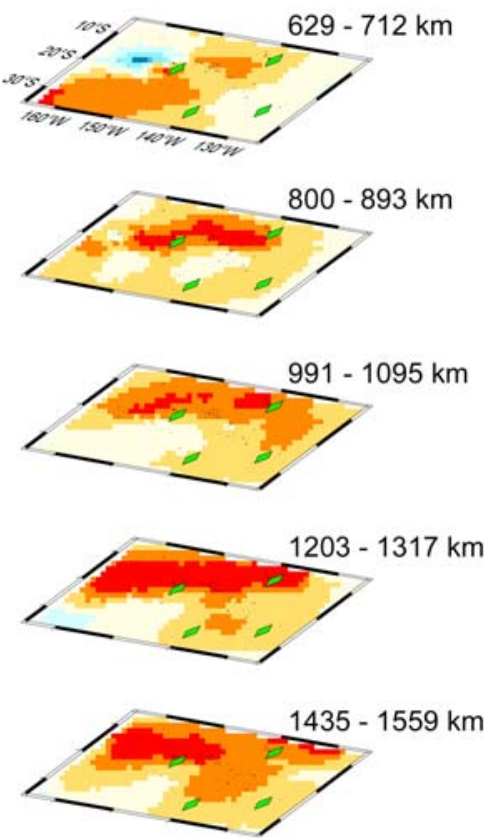

$1.0 \%$ fast

Figure 10. Comparison of $P$ wave tomograms obtained (a) with ISC, PLUME, and BBOBS data and (b) with the ISC-only data. Note that the abrupt change in dimension of slow velocity anomalies is found at $1000 \mathrm{~km}$ depth with PLUME, BBOBS, and ISC data, while it is not visible with the ISC-only data. Green diamonds are active hot spots.

mantle model $(\sim 500 \mathrm{~km})$. The distribution of the MTZ thickness, however, supports the presence of these narrow anomalies. Beneath the Society hot spots, two significantly thin MTZ were found (Figure 7), which were close to the narrow anomalies at the top of the lower mantle (Figures 9 and 11). The two areas of thinned MTZ were also located near the two slow anomalies in the upper mantle beneath the Society hot spots (Figure 5c), which suggests that they represent two continuous plumes that ascend from the top surface of the superplume to the Society hot spot (the A-A' cross section in Figure 11). The location of the thin MTZ northwest of the Macdonald hot spot (Figure 7a) also roughly coincides with the slow anomalies in the upper mantle (Figures 4 and 5a) and in the top of the lower mantle (Figure 9), suggesting a continuous plume from the lower mantle (the $\mathrm{C}-\mathrm{C}^{\prime}$ cross section of Figure 11). In contrast, the slow anomalies beneath the Marquesas hot spot (Figures 4 and 5c) seem to be restricted to the upper mantle, and there is no evidence of slow anomalies at the top of the lower mantle beneath this region (Figure 9). The MTZ thickness also appears to be normal beneath the Marquesas hot spot (Figure 7). We therefore consider that there are no plumes continuously rising from the lower mantle to the Marquesas hot spot. The Pitcairn hot spot is characterized by a slow upper mantle (Figure 5c) and a thin MTZ (Figure 7), but with no slow anomalies at the top of the lower mantle (Figure 9). The Pitcairn hot spot may therefore have its origin in the MTZ. The Arago hot spot has only a weak slow anomaly (relative to the surrounding regions) in the uppermost mantle (Figure 5a), and a normal MTZ thickness (Figure 7), indicating that its origin is likely from a shallow feature in the uppermost mantle. The most remarkable feature in Figure 11 is the abrupt change in the scale of the slow anomalies within the lower mantle: they are several thousand kilometers at depths greater than $1000 \mathrm{~km}$, and few hundred kilometers above it. Such an observation can be resolved only by incorporating both BBOBS and PLUME data, along with the data from permanent stations. Without the temporary networks, the superplume is imaged as a continuous structure across the entire lower mantle (Figure 10b).

[26] One notable observation in the South Pacific region is the seafloor swell. It is characterized by two different spatial length scales: wide shallow regions around hot spots on a scale of several 

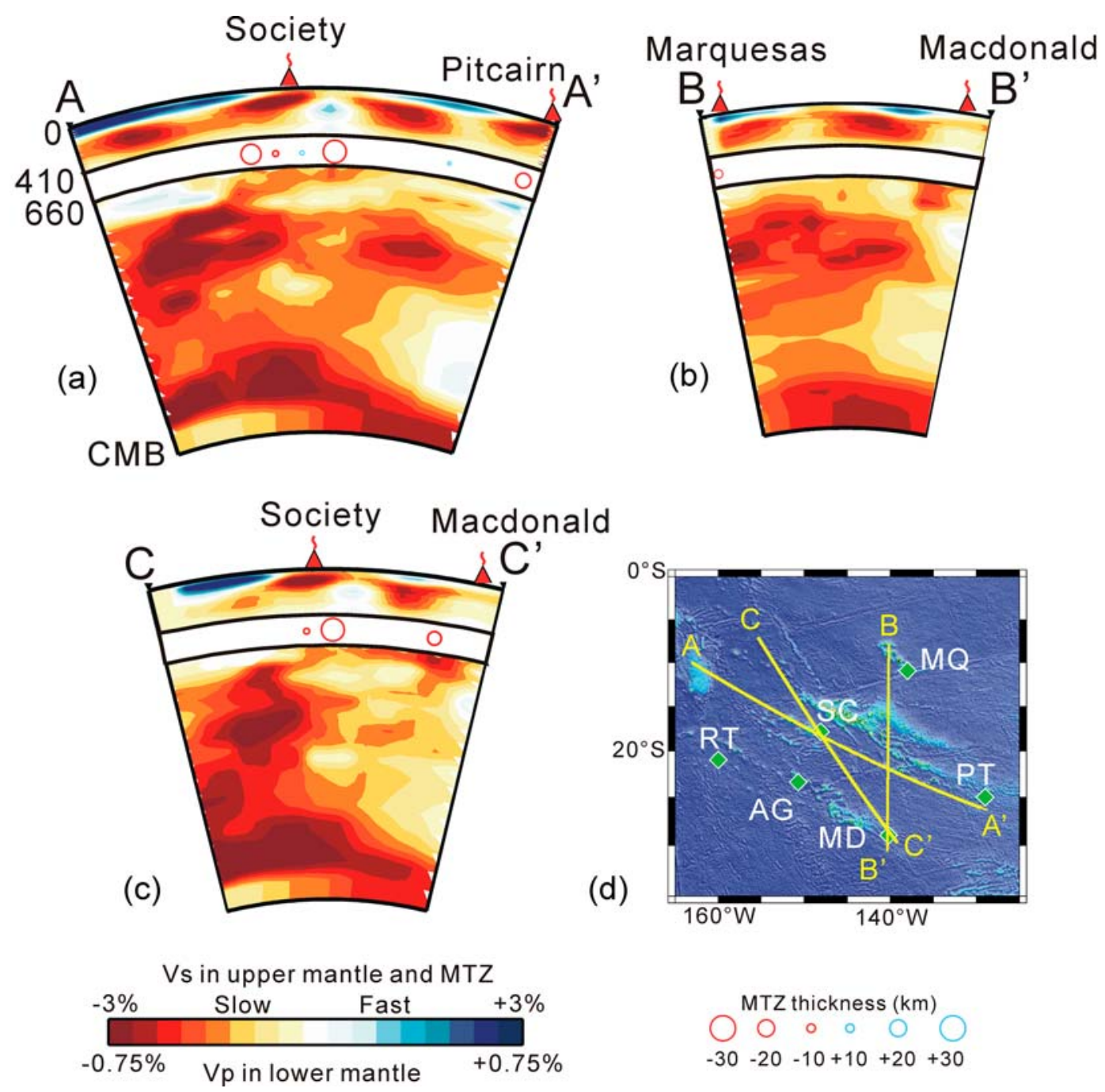

Figure 11. $(a-c)$ Cross sections of seismic structure in the entire mantle. $\mathrm{S}$ wave velocities are shown for the upper mantle $(0-410 \mathrm{~km})$. P wave velocities are shown for the lower mantle $(660-2900 \mathrm{~km})$. Velocity scales are $\pm 3 \%$ in the upper mantle and $\pm 0.75 \%$ in the lower mantle. (d) Positions of the profiles. The abbreviated names of the hot spot in Figure 11d are the same as in Figure 4. Circles plotted in the MTZ $(410-660 \mathrm{~km})$ are the locations of the MTZ thickness estimated near the profiles within $2.5^{\circ}$, where red and blue represent thicker and thinner than the global average, respectively, and the size is proportional to the deviation from the average. Green diamonds in Figure 11d are active hot spots.

hundred to a thousand kilometers (hot spot swell), and a huge shallow region on a scale of several thousand kilometers (the South Pacific superswell). Adam et al. [2007] simulated an instantaneous mantle flow driven by density heterogeneities, which were deduced from the upper mantle $\mathrm{S}$ wave velocity anomalies obtained by the present study. In their computation they assumed a highly viscous $\left(10^{23} \mathrm{~Pa} \cdot \mathrm{s}\right)$ lithosphere and a less viscous asthenosphere $\left(10^{20} \mathrm{~Pa} \cdot \mathrm{s}\right)$. The dynamic topography computed from the mantle flow indicated the locations, sizes, and amplitudes of the observed hot spot swell very well. Interestingly, the hot spot swell northwest of the Macdonald hot spot is also cor- rectly reproduced by the upper mantle upwelling that corresponds to the slow anomalies located 200-300 km northwest of the hot spot (Figures 4 and 5a). These results will be discussed in more detail in a companion paper. The lateral dimension of the superplume imaged by the present study is similar to that of the observed superswell [Adam and Bonneville, 2005], which encourages us to also explain the superswell as being dynamic topography directly related to the superplume. While our preliminary results showed that the lateral dimension and amplitude of the superswell could be explained by the superplume (C. Adam, personal communication, 2009), ongoing further quantita- 


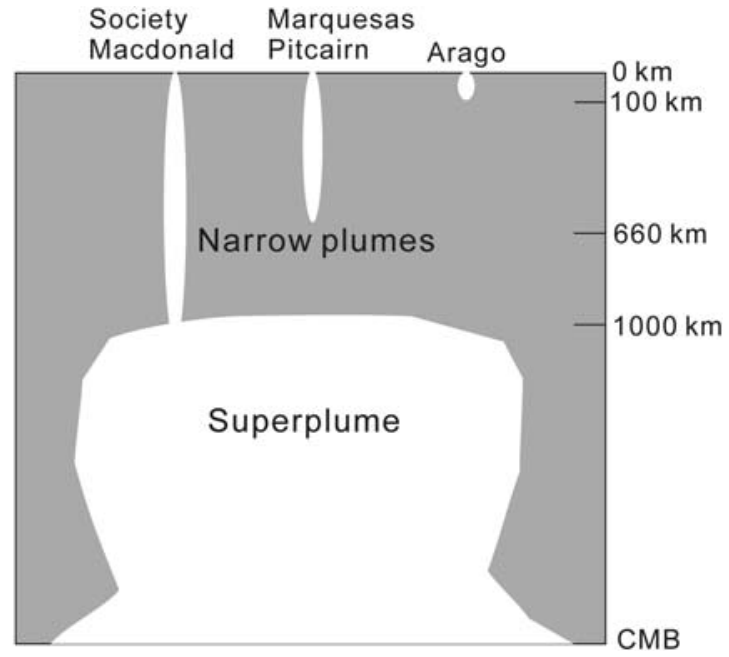

Figure 12. A cartoon illustrating the possible relationships between the deep superplume and narrower and shallower plumes beneath the South Pacific superswell. The superplume is located in the lower mantle from the core-mantle boundary to $1000 \mathrm{~km}$ depth. Narrow plumes beneath the hot spots may have various depth origins. The Society and Macdonald hot spots are likely deeply rooted down to the superplume head, while other hot spots may have origins in the transition zone (Pitcairn and perhaps Marquesas) or in the uppermost mantle (Arago).

tive modeling of the superswell by dynamic topography is required to confirm this.

[27] What are the superplume and the narrow plumes? Are they purely thermally driven, or chemically distinct, or both? The traditional view of the ascending process of a mantle thermal plume is that a hot upwelling in the lower mantle is stuck below the " 660 " because of the negative buoyancy acting upon the hot upwelling, due to the endothermic phase transformation at the " 660 " [e.g., Vinnik et al., 1997]. This view leads to speculation that a superplume may be stagnant, and is spreading laterally immediately beneath the "660." Such a laterally spreading superplume could generate secondary narrow plumes due to thermal instability, which may be responsible for hot spots at the surface. The present study, however, reveals that the top of the superplume is located at a depth of $1000 \mathrm{~km}$, which is well below the "660," but it also reveals the absence of broad slow anomalies immediately beneath the "660," which is clearly inconsistent with this scenario. Furthermore, the shape of the superplume imaged by the present study is quite different from the shape one would expect for thermal plumes on the basis of laboratory and numerical experiments, which often show that purely thermal plumes are characterized by a broad head and a narrow tail. All this makes it difficult to interpret the superplume as being purely thermal.

[28] One possible interpretation of the superplume and narrow plumes is that a thermochemical dome and secondary plumes generated at the top of the dome [e.g., Courtillot et al., 2003], respectively, as is schematically illustrated in Figure 12. The thermochemical dome or plume does not necessarily have a broad head and narrow tail. Laboratory experiments performed in tanks using two chemically distinct layers, with a slightly denser and more viscous lower layer, show that the lower layer develops a large dome that protrudes into the upper layer as the bottom of the lower layer is heated [Davaille, 1999; Kumagai et al., 2007]. From the top of the dome, narrow secondary plumes are occasionally generated and ascend [Davaille et al., 2002], and display a geometry that is similar to the superplume and narrow plumes imaged by the present study. The slow anomalies beneath the hot spots other than the Society and Macdonald hot spots are not connected to the lower mantle slow anomalies (Figures 11 and 12). They may represent (remnant) secondary plumes that have detached from the superplume, though a shallower origin has been also proposed for some hot spots (e.g., Marquesas, Arago) [McNutt and Bonneville, 2000; Bonneville et al., 2002]. Since the intrinsic density contrast of the two layers is marginally balanced by the density difference of thermal origin, the dome moves up and down quasiperiodically. The development of the dome structure has also been also demonstrated by two- and three-dimensional numerical simulations [McNamara and Zhong, 2004; Farnetani and Samuel, 2005; Ogawa, 2007]. Experiments have also shown that secondary plumes are generated sporadically and do not last for a long time [Davaille, 1999; Ogawa, 2007], which may explain the short age progressions of the Polynesian hot spots [Duncan and MacDougall, 1976; Clouard and Bonneville, 2005]. At the bottom of the mantle beneath the South Pacific, a simultaneous analysis of geoid and free oscillation detected a high density anomaly that is likely of chemical origin [Ishii and Tromp, 1999], which supports the idea of a thermochemical superplume. If we assume that secondary plumes entrain chemically distinct superplume materials, as they should, then this may explain the origin of the enriched mantle signature found in the South Pacific OIB. If the superplume has geochemical 
heterogeneities inside it, different narrow plumes may be composed of small and differing portions of the superplume, and thus display different geochemical signatures (e.g., abundance of trace elements, isotopic ratios of radiogenic elements) at different hot spots, as has been observed in the South Pacific [e.g., Bonneville et al., 2006]. In a laboratory experiement, Davaille [1999] showed that the superplume or dome oscillates vertically. If this is the case for the South Pacific superplume, the oscillation should cause the pulsation of volcanic activity in the South Pacific. At present, the South Pacific hot spots are relatively quiet in terms of volcanic activity, possibly because the superplume is located deep in the lower mantle. The vertical oscillation may, however, have caused an uprise of the superplume in the past, which could be responsible for the increase in the production rate of large oceanic plateaus during the Cretaceous period, as has been proposed in previous studies [e.g., Larson, 1991; Utsunomiya et al., 2007].

[29] To examine whether the narrow plumes are continuously ascending from the lower mantle through the MTZ to the upper mantle, it is desirable to obtain a high-resolution whole mantle tomogram using a single method (e.g., $\mathrm{P}$ wave travel time tomography, waveform inversion), although this remains unfeasible with the still sparse station coverage available in the present study. For this reason we combined the upper mantle $\mathrm{S}$ velocity model, the MTZ thickness, and the lower mantle $\mathrm{P}$ velocity model in order to see the structure of the entire mantle (Figure 11). To overcome the difficulty of imaging the connection of slow velocity anomalies between the upper and lower mantle, a new seafloor observation effort that is equipped with a denser BBOBS array focused around the Society hot spot, was begun earlier this year (2009) and will continue through 2010. This effort should provide us with a more definitive answer as to the origin depth of the Society hot spot, and its connection with the lower mantle superplume.

\section{Acknowledgments}

[30] The PLUME experiment was funded by the French Ministère de la Recherche, Action Concertée Incitative (ACI) jeunes chercheurs, and by the Ministère de l'Outre Mer. The portable seismic stations were provided by the Institut National des Sciences de l'Univers (INSU), and Réseau Large Bande Mobile (RLBM). We are extremely grateful to Météo France and Aviation Civile for installing seismic stations at their sites and for the help provided by their personnel, and by the municipalities of the Polynesian Islands.
The BBOBS experiment has been supported by a Grant-in-Aid for Scientific Research $(16253002,19253004)$ from the Japan Society for the Promotion of Science. We wish to emphasize that the successful deployment and recovery of the BBOBS was made possible by the efforts of Captain S. Ishida and Captain F. Saito and the crew of the R/V YOKOSUKA, the Shinkai-6500 operation team, and the JAMSTEC administration. Many thanks also, to the Centre National de la Recherche Scientifique (CNRS), the Government of French Polynesia, the Université de Polynésie Française (UPF), the Haut-Commissariat de la Polynésie Française, and the Commissariat à l'Energie Atomique (CEA) for making our experiments possible. Many thanks to C. Adam, E. Debayle, Y. Vota, B. Jouanneau, A. Vauchez, C. Zaroli, M. Yoshida, and O. Hyvernaud for their help in the experiments and discussion. This paper has been greatly improved by the comments of Alain Bonneville and an anonymous reviewer. We also thank IRIS and GEOSCOPE for maintaining their permanent stations and making their data available to the public.

\section{References}

Adam, C., and A. Bonneville (2005), Extent of the South Pacific Superswell, J. Geophys. Res., 110, B09408, doi:10.1029/2004JB003465.

Adam, C., M. Yoshida, T. Isse, D. Suetsugu, H. Shiobara, H. Sugioka, T. Kanazawa, Y. Fukao, and G. Barruol (2007), French Polynesia Hotspot swells explained by dynamic topography, Eos Trans. AGU, 88(52), Fall Meet. Suppl., Abstract T21B-0599.

Barruol, G., et al. (2002), PLUME investigates the South Pacific Superswell, Eos Trans. AGU, 83, 511-514, doi:10.1029/2002EO000354.

Barruol, G., D. Reymond, F. R. Fontaine, O. Hyvernaud, V. Maurer, and K. Maamaatuaiahutapu (2006), Characterizing swells in the southern Pacific from seismic and infrasonic noise analyses, Geophys. J. Int., 164, 516-542, doi:10.1111/ j.1365-246X.2006.02871.x.

Barruol, G., D. Suetsugu, H. Shiobara, H. Sugioka, S. Tanaka, G. H. R. Bokelmann, F. R. Fontaine, and D. Reymond (2009), Mapping upper mantle flow beneath French Polynesia from broadband ocean bottom seismic observations, Geophys. Res. Lett., 36, L14301, doi:10.1029/2009GL038139.

Bassin, C., G. Laske, and G. Masters (2000), The current limits of resolution for surface wave tomography in North America, Eos Trans. AGU, 81(48), Fall Meet. Suppl., Abstract S12A-03.

Bonneville, A., R. Le Suavé, L. Audin, V. Clouard, L. Dosso, P. Y. Gillot, A. Hildenbrand, P. Janney, K. Jordahl, and K. Maamaatuaiahutapu (2002), Arago Seamount: The missing hotspot found in the Austral Islands, Geology, 30(11), 1023-1026, doi:10.1130/0091-7613(2002)030<1023: ASTMHF $>2.0 . \mathrm{CO} ; 2$.

Bonneville, A., L. Dosso, and A. Hildenbrand (2006), Temporal evolution and geochemical variability of the South Pacific superplume activity, Earth Planet. Sci. Lett., 244, 251-269, doi:10.1016/j.epsl.2005.12.037.

Clouard, V., and A. Bonneville (2005), Ages of seamounts, islands and plateaus on the Pacific plate, in Plates, Plumes, and Paradigms, edited by G. R. Foulger et al., Geol. Soc. Am. Bull., 388, 71-90, doi:10.1130/2005.2388(06).

Courtillot, V., A. Davaille, J. Besse, and J. Stock (2003), Three distinct types of hotspots in the Earth's mantle, Earth Planet. 
Sci. Lett., 205, 295-308, doi:10.1016/S0012-821X(02) 01048-8.

Dahlen, F. A., S.-H. Hung, and G. Nolet (2000), Fréchet kernels for finite-frequency traveltimes-Theory I., Geophys. $J$. Int., 141, 157-174, doi:10.1046/j.1365-246X.2000.00070.x.

Davaille, A. (1999), Simultaneous generation of hotspots and superswells by convection in a heterogeneous planetary mantle, Nature, 402, 756-760, doi:10.1038/45461.

Davaille, A., F. Girard, and M. Le Bars (2002), How to anchor hotspots in a convecting mantle?, Earth Planet. Sci. Lett., 203, 621-634, doi:10.1016/S0012-821X(02)00897-X.

Duncan, R., and I. MacDougall (1976), Linear volcanism in French Polynesia, J. Volcanol. Geotherm. Res., 1, 197-227, doi:10.1016/0377-0273(76)90008-1.

Dziewonski, A., and D. L. Anderson (1981), Preliminary reference Earth model, Phys. Earth Planet. Inter., 25, 297356, doi:10.1016/0031-9201(81)90046-7.

Dziewonski, A. M., and A. L. Hales (1972), Numerical analysis of dispersed seismic waves, in Seismology: Surface Waves and Earth Oscillations, Methods Comput. Phys., 11, $39-85$.

Efron, B., and R. Tibshirani (1986), Bootstrap methods for standard errors, confidence intervals, and other measures of statistical accuracy, Stat. Sci., 1, 54-77, doi:10.1214/ss/ 1177013815.

Farnetani, C. G., and H. Samuel (2005), Beyond the thermal plume paradigm, Geophys. Res. Lett., 32, L07311, doi:10.1029/2005GL022360.

Flanagan, M., and P. Shearer (1998), Global mapping of topography on transition zone velocity discontinuities by stacking SS precursors, J. Geophys. Res., 103, 2673-2692, doi:10.1029/97JB03212.

Fontaine, F. R., G. Barruol, A. Tommasi, and G. H. R. Bokelmann (2007), Upper mantle flow beneath French Polynesia from shear-wave splitting, Geophys. J. Int., 170, 12621288, doi:10.1111/j.1365-246X.2007.03475.x.

Fontaine, F. R., G. Barruol, B. L. N. Kenneth, G. H. R. Bokelmann, and D. Reymond (2009), Upper mantle anisotropy beneath Australia and Tahiti from P wave polarization: Implication for real-time earthquake location, J. Geophys. Res., 114, B03306, doi:10.1029/2008JB005709.

Fukao, Y., A. To, and M. Obayashi (2003), Whole mantle $P$ wave tomography using $P$ and PP-P data, J. Geophys. Res., 108(B1), 2021, doi:10.1029/2001JB000989.

Gu, Y. J., A. M. Dziewonski, and C. B. Agee (1998), Global de-correlation of the topography of transition zone discontinuities, Earth Planet. Sci. Lett., 157, 57-67, doi:10.1016/ S0012-821X(98)00027-2.

Gurrola, H., J. B. Minster, and T. Owens (1994), The use of velocity spectrum for stacking receiver functions and imaging upper mantle discontinuities, Geophys. J. Int., 117, 427-440, doi:10.1111/j.1365-246X.1994.tb03942.x.

Hart, S. R. (1984), A large-scale isotope anomaly in the southern hemisphere mantle, Nature, 309, 753-757, doi:10.1038/ $309753 \mathrm{a} 0$.

Helffrich, G. (2000), Topography of the transition zone seismic discontinuities, Rev. Geophys., 38, 141-158, doi:10.1029/ 1999RG000060.

Irifune, T., et al. (1998), The postspinel phase boundary in $\mathrm{Mg}_{2} \mathrm{SiO}_{4}$ determined by in situ X-ray diffraction, Science, 279, 1698-1700, doi:10.1126/science.279.5357.1698.

Ishida, M., S. Maruyama, D. Suetsugu, S. Matsuzaka, and T. Eguchi (1999), Superplume Project: Towards a new view of whole Earth dynamics, Earth Planets Space, 51, 1-5.

Ishii, M., and J. Tromp (1999), Normal-mode and free-air gravity constraints on lateral variation in velocity and density of Earth's mantle, Science, 285, 1231-1236, doi:10.1126/ science.285.5431.1231.

Isse, T., D. Suetsugu, H. Shiobara, H. Sugioka, K. Yoshizawa, T. Kanazawa, and Y. Fukao (2006), Shear wave speed structure beneath the South Pacific superswell using broadband data from ocean floor and islands, Geophys. Res. Lett., 33, L16303, doi:10.1029/2006GL026872.

Kanazawa, T., M. Mochizuki, and H. Shiobara (2001), Broadband seismometer for a long-term observation on the sea floor, paper presented at the Ocean Hemisphere Network Project/International Ocean Network Joint Symposium on Long-Term Observations in the Oceans: Current Status and Perspectives for the Future, Yamanakako, Japan.

Katsura, T., et al. (2004), Olivine-wadsleyite transition in the system $(\mathrm{Mg}, \mathrm{Fe})_{2} \mathrm{SiO}_{4}$, J. Geophys. Res., 109, B02209, doi:10.1029/2003JB002438.

Kennett, B. L. N., and E. R. Engdahl (1991), Traveltimes for global earthquake location and phase identification, Geophys. J. Int., 105, 429-465, doi:10.1111/j.1365-246X.1991. tb06724.x.

Kennett, B. L. N., and O. Gudmundsson (1996), Ellipticity corrections for seismic phases, Geophys. J. Int., 127, 4048, doi:10.1111/j.1365-246X.1996.tb01533.x.

Kumagai, I., A. Davaille, and K. Kurita (2007), On the fate of thermally buoyant mantle plumes at density interfaces, Earth Planet. Sci. Lett., 254, 180-193, doi:10.1016/ j.epsl.2006.11.029.

Langston, C. A. (1977), The effect of planar dipping structure on source and receiver responses for constant ray parameter, Bull. Seismol. Soc. Am., 67, 1029-1050.

Larson, R. L. (1991), Latest pulse of Earth: Evidence for a midCretaceous superplume, Geology, 19, 547-550, doi:10.1130/ 0091-7613(1991)019<0547:LPOEEF >2.3.CO;2.

Maggi, A., E. Debayle, K. Priestley, and G. Barruol (2006a), Multi-mode surface waveform tomography of the Pacific ocean: A closer look at the lithopsheric cooling signature, Geophys. J. Int., 166, 1384-1397, doi:10.1111/j.1365246X.2006.03037.x.

Maggi, A., E. Debayle, K. Priestley, and G. Barruol (2006b), Azimuthal anisotropy of the Pacific region, Earth Planet. Sci. Lett., 250, 53-71, doi:10.1016/j.eps1.2006.07.010.

Masters, G., G. Laske, H. Bolton, and A. Dziewonski (2000), The relative behavior of shear velocity, bulk sound speed, and compressional velocity in the mantle: Implications for chemical and thermal structure, in Earth's Deep Interior, Geophys. Monogr. Ser., vol. 117, edited by S. Karato et al., pp. 63-87, AGU, Washington, D. C.

McNamara, A. K., and S. Zhong (2004), Thermochemical structures within a spherical mantle: Superplumes or piles?, J. Geophys. Res., 109, B07402, doi:10.1029/2003JB002847.

McNutt, M. (1998), Superswells, Rev. Geophys., 36, 211-244, doi:10.1029/98RG00255.

McNutt, M., and A. Bonneville (2000), A shallow, chemical origin for the Marquesas Swell, Geochem. Geophys. Geosyst., 1(6), 1014, doi:10.1029/1999GC000028.

McNutt, M., and A. Judge (1990), The superswell and mantle dynamics beneath the south Pacific, Science, 248, 969-975, doi:10.1126/science.248.4958.969.

Mégnin, C., and B. Romanowicz (2000), The three-dimensional shear velocity structure of the mantle from the inversion of body, surface and higher-mode waveforms, Geophys. J. Int., 143, 709-728, doi:10.1046/j.1365-246X.2000.00298.x.

Montelli, R., G. Nolet, F. A. Dahlen, and G. Masters (2006), A catalogue of deep mantle plumes: New results from finitefrequency tomography, Geochem. Geophys. Geosyst., 7, Q11007, doi:10.1029/2006GC001248. 
Niu, F., S. C. Solomon, P. G. Silver, D. Suetsugu, and H. Inoue (2002), Mantle transition-zone structure beneath the South Pacific Superswell and evidence for a mantle plume underlying the Society hotspot, Earth Planet. Sci. Lett., 198, $371-380$.

Ogawa, M. (2007), Superplumes, plates, and mantle magmatism in two-dimensional numerical models, J. Geophys. Res., 112, B06404, doi:10.1029/2006JB004533.

Owens, T. J., and R. S. Crosson (1988), Shallow structure effects on broadband teleseismic P waveforms, Bull. Seismol. Soc. Am., 78, 96-108.

Paige, C. C., and M. A. Saunders (1982), LSQR: An algorithm for sparse linear equations and sparse least squares, Trans. Math. Software, 8, 43-71, doi:10.1145/355984.355989.

Ritsema, J., and H. J. van Heijst (2000), Seismic imaging of structural heterogeneity in Earth's mantle: Evidence for large-scale mantle flow, Sci. Prog., 83, 243-259.

Romanowicz, B., and Y. Gung (2002), Superplumes from the core-mantle boundary to the lithosphere: Implications for heat flux, Science, 296, 513-516, doi:10.1126/ science. 1069404.

Saita, T., D. Suetsugu, T. Ohtaki, H. Takenaka, K. Kanjo, and I. Purwana (2002), Transition zone thickness beneath Indonesia as inferred using the receiver function method for data from the JISNET regional broadband seismic network, Geophys. Res. Lett., 29(7), 1115, doi:10.1029/2001GL013629.

Suetsugu, D., T. Saita, H. Takenaka, and F. Niu (2004), Thickness of the mantle transition zone beneath the South Pacific as inferred from analyses of ScS reverberated and Ps converted waves, Phys. Earth Planet. Inter., 146, 35-46, doi:10.1016/j.pepi.2003.06.008.

Suetsugu, D., et al. (2005a), Probing South Pacific mantle plumes with ocean bottom seismographs, Eos Trans. $A G U$, 86, 429-435, doi:10.1029/2005EO440001.

Suetsugu, D., et al. (2005b), Mantle discontinuity depths beneath the West Philippine Basin from receiver function analysis of deep-sea borehole and seafloor broadband waveforms, Bull. Seismol. Soc. Am., 95, 1947-1956, doi:10.1785/ 0120040169 .
Suetsugu, D., H. Shiobara, H. Sugioka, Y. Fukao, and T. Kanazawa (2007), Topography of the mantle discontinuities beneath the South Pacific superswell as inferred from broadband waveforms on seafloor, Phys. Earth Planet. Inter. 160, 310-318, doi:10.1016/j.pepi.2006.11.011.

Takeuchi, N. (2007), Whole mantle SH-velocity model constrained by waveform inversion based on three-dimensional Born kernels, Geophys. J. Int., 169(3), 1153-1163, doi:10.1111/j.1365-246X.2007.03405.x.

Takeuchi, N. (2009), A low-velocity conduit throughout the mantle in the robust component of a tomographic model, Geophys. Res. Lett., 36, L07306, doi:10.1029/ 2009GL037590.

Tanaka, S., M. Obayashi, D. Suetsugu, H. Shiobara, H. Sugioka, J. Yoshimitsu, T. Kanazawa, Y. Fukao, and G. Barruol (2009a), P wave tomography of the mantle beneath the South Pacific Superswell revealed by joint ocean floor and island broadband seismic experiments, Phys. Earth Planet. Inter. 172, 268-277, doi:10.1016/j.pepi.2008.10.016.

Tanaka, S., D. Suetsugu, H. Shiobara, H. Sugioka, T. Kanazawa, Y. Fukao, G. Barruol, and D. Reymond (2009b), On the vertical extent of the large low shear velocity province beneath the South Pacific Superswell, Geophys. Res. Lett., 36 , L07305, doi:10.1029/2009GL037568.

Tarantola, A., and B. Valette (1982), Generalized nonlinear inverse problems solved using the least-squares criterion, Rev Geophys., 20, 219-232, doi:10.1029/RG020i002p00219.

Utsunomiya, A., T. Ota, B. F. Windley, N. Suzuki, Y. Uchio, K. Munekata, and S. Maruyama (2007), History of the Pacific Superplume: Implications for Pacific paleogeography since the late Proterozoic, in Superplumes: Beyond Plate Tectonics, edited by D. A. Yuen et al., pp. 363-408, Springer, Dordrecht, Netherlands.

Vinnik, L., S. Chevrot, and J.-P. Montagner (1997), Evidence for a stagnant plume in the transition zone?, Geophys. Res. Lett., 24, 1007-1010, doi:10.1029/97GL00786.

Zhao, D. (2004), Global tomographic images of mantle plumes and subducting slabs: Insight into deep Earth dynamics, Phys. Earth Planet. Inter., 146, 3-34, doi:10.1016/ j.pepi.2003.07.032. 